\title{
Chicago's Ban on Gang Loitering: Making Sense of Vagueness and Overbreadth in Loitering Laws
}

\author{
Peter W. Poulos $\uparrow$
}

Concern about increasing crime has motivated many municipalities across the county to enact loitering laws specifically aimed at drug activity, prostitution, violent crime, and criminal gangs. Such laws often reach innocent or constitutionally protected activity, causing them to be susceptible to arbitrary or discriminatory enforcement by law enforcement officials. Additionally, such laws may have a chilling effect on the exercise of First Amendment freedoms. Against the specific background of a Chicago loitering ordinance aimed at gang activity, as well as loitering ordinances generally, this Comment examines the doctrines of vagueness and overbreadth. The Comment takes note of the similarity of the doctrines' operation in First Amendment cases, and develops a unified approach for analyzing vagueness and overbreadth in loitering laws. The unified approach is then applied to the Chicago gang loitering ordinance, with the conclusion that it is unlikely to survive challenges based on vagueness and overbreadth. The author offers an alternate version of the Chicago ordinance, designed to withstand vagueness and overbreadth challenges, but notes that practical problems in enforcement remain. The author concludes the Comment with some thoughts on the current utility of loitering laws in the effort to prevent crime.

\section{INTRODUCTION}

The Chicago City Council, frustrated by a spiraling crime rate allegedly resulting from gang violence, has given its police the power to take back street corners from gangs. On June 17, 1992, ${ }^{1}$ the City Council passed Section 8-4-015 of the Chicago Municipal Code ("Ordinance") authorizing police officers to order groups of loiterers to disperse or face arrest where

Copyright $\odot 1995$ California Law Review, Inc.

$\dagger$ B.S. 1990, University of Illinois at Urbana-Champaign; C.P.A.; J.D. candidate 1995, Boalt Hall School of Law, University of California, Berkeley. I would like to thank Professor Martin Shapiro for lis feedback and encouragement, and Jennifer Gillum and my other friends and colleagues on the California Law Review for their thoughtful editing. Special thanks to my parents, Georgia and William Poulos, for their unwavering support.

1. Martha Middleton, Gang Law Will Meet Court Test, NaT'L L.J., July 20, 1992, at 3. 
the officer reasonably believes that one of the loiterers is a gang member. ${ }^{2}$ To no one's surprise, the Ordinance has ignited a vigorous and often angry debate:

"In some areas of the city, street gangs are terrorizing residents and laying claim to whole communities."

\author{
Richard Daley ${ }^{3}$ \\ Mayor
}

2. Chicago, Ill., Mun. Code § 8-4-015 (1993). Section 8-4-015 provides:

(a) Whenever a police officer obscrves a person whom he reasonably believes to be [a] criminal street gang member loitering in any public place with one or more other persons, he shall order all such persons to disperse and remove themselves from the area. Any person who does not promptly obey such an order is in violation of this scction.

(b) It shall be an affirmative defense to an alleged violation of this section than no person who was observed loitering was in fact a member of a criminal strect gang.

(c) As used in this Section:

(1) "Loiter" means to remain in any one place with no apparent purpose.

(2) "Criminal street gang" means any ongoing organization, association in faet or group of three or more persons, whether formal or informal, having as one of its substantial activitics the commission of one or more of the criminal acts enumerated in paragraph (3), and whose members individually or collectively engage in or have engaged in a pattern of criminal gang activity.

(3) "Criminal gang activity" means the commission, attempted commission, or solicitation of the following offenses, provided that the offenses are committed by two or more persons, or by an individual at the direction of, or in association with, any criminal street gang, with the specific intent to promote, further, or assist in any criminal conduct by gang members:

The following Sections of the Criminal Code of 1961: 9-1 (murder), 9-3.3 (drug induced homicide), 10-I (kidnapping), 10-4 (forcible detention), subsection (a)(13) of Section 12-2 (aggravated assault-discharging firearm), 12-4 (aggravated battery), 12-4.1 (beinous battery), 12-4.2 (aggravated battery with a firearm), 12-4.3 (aggravated battery of a ehild), 12-4.6 (aggravated battery of a senior citizen), 12-6 (intimidation), 12-6.1 (compelling organization membership of persons), 12-11 (home invasion), 12-14 (aggravated criminal sexual assault), 18-1 (robbery), 18-2 (armed robbery), 19-1 (hurglary), 19-3 (residential burglary), 19-5 (criminal fortification of a residence or building), 20-1 (arson), 20-1.1 (aggravated arson), 202 (possession of explosives or explosive or incendiary devices), subsection (a)(6), (a)(7), (a)(9) or (a)(12) of Section 24-1 (unlawful use of weapons), 24-1.1 (unlawful use or possession of weapous by felons or persons in the custody of the Department of Corrections facilities), 24-1.2 (aggravated discharge of a firearm), subsection (d) of Section 25-1 (mob action-violence), 33-I (bribery)[] 33A-2 (armed violence); Sectious 5, 5.1, 7 or 9 of the Cannabis Control Act where the offense is a felony (manufacture or delivery of cannabis, cannabis trafficking, calculated criminal cannabis conspiracy and related offenses); or Sections $401,401.1,405,406.1,407$ or 407.1 of the Illinois Controlled Substanees Act (illegal manufacture or delivery of a controlled substance, controlled substance traffieking, calculatcd criminal drug conspiracy and related offenses).

(4) "Pattern of criminal gang activity" means two or more acts of criminal gang activity of which at least two such acts were committed within five years of each other and at least one such act occurred after the effective date of this Section.

(5) "Public place" means the public way and any other location open to the public, whether publicly or privateiy owned.

(e) Any person who violates this Section is subject to a fine of not less than $\$ 100$ and not more than $\$ 500$ for each offense, or imprisoument for not more than six months, or both.

In addition to or instead of the above penalties, any person who violates this section may be required to perform up to 120 hours of community service pursuant to seetion 1-4-120 of this Code. at $5 \mathrm{~A}$.

3. Kevin Johnson, Chicago's New Gang Ordinance Creates Concern, USA TodaY, July 8, 1992, 
"It's difficult for ordinary people to even coine out of their hoines because of the shooting and gang activity."

Ed Smith

Alderman ${ }^{4}$

"Something has to be done. I don't see how it could get much worse."

\section{Bobbie Crawford \\ Waitress 5}

"When kids reach a certain age they hang around on street corners. I sure wouldn't like my children taken to a police station for hanging around."

\section{Joan Suglich \\ Mother of $\mathrm{Six}^{6}$}

"What if somebody asks his boys to walk him home so [gang meinbers] don't jump him. Are the police going to arrest thein?"

\section{Patrick \\ Gang Member ${ }^{7}$}

This same debate is being repeated in a number of cities across the Umited States. In an atteinpt to check rapidly increasing crime, local governments are enacting loitering laws aimed at drugs, prostitution, and violent crime. For example, Seattle, Washington passed an ordinance prohibiting loitering in public places by persons with the intent to sell drugs. ${ }^{8}$ Under the Seattle ordinance, arrests can be made for signaling or beckoning to passersby, possessing drug paraphernalia, or being a known drug dealer. ${ }^{9}$ Similarly, Tampa, Florida, passed an ordinance proscribing loitering in a manner and under circumstances manifesting a purpose of inducing, enticing, soliciting, or procuring another to commit an act of prostitution. ${ }^{10}$ The Tampa law listed the fact that a person is a known prostitute as such a circumstance. ${ }^{11}$

Laws such as these are designed to control criminal activity. But such laws also may reach activity that is generally innocent or constitutionally protected, creating the potential for abuse and arbitrary enforceinent by law

\section{Id.}

5. Frank James, Many Stand Up For Law on Loitering, CFr. TriB., June 21, 1992, § 2, at 1.

6. Johnson, supra note 3.

7. James, supra note 5 , at 3 (alteration in original).

8. Don Williamson, Loitering Law: A Day Without Winners, SEATrLe Times, Jnly 3, 1990, at A10.

9. Id.

10. Wyche v. State, 619 So. $2 d$ 231, 233 n.2 (Fla. 1993).

11. Id. 
enforcement officials. ${ }^{12}$ Loitering laws potentially can also cause a chilling effect on protected First Amendment freedoms. Based on these concerns, a number of groups are challenging the constitutionality of these loitering laws. The results of the challenges have been mixed. For instance, the Florida Supreme Court struck down the Tampa loitering ordinance targeting prostitution. ${ }^{13}$ In contrast, the Washington Supreme Court upheld the validity of a drug loitering ordinance that is nearly identical to the Seattle ordinance mentioned above. ${ }^{14}$

This Comment focuses on vagueness and overbreadth, two common constitutional challenges to loitering laws. ${ }^{15}$ The void-for-vagueness doctrine emanates from the Due Process Clauses of the Fifth and Fourteenth Amendments. ${ }^{16}$ The doctrine requires: (1) that a law give people of ordinary intelligence notice of what is prohibited, and (2) that a law provide explicit standards to law enforcement officers in order to avoid arbitrary and discriminatory enforcement. ${ }^{17}$ In contrast, the overbrcadth doctrine stems from the First Amendment. A statute is overbroad if, in addition to proscribing activities that are not constitutionally protected, it covers activities that are protected by the First Amendment. ${ }^{18}$

12. For example, loitering gencrally includes strolling or walking with no specific place to go. Such behavior by itself is usually considered not only inherently innocent, but constitutionally protected. See Papachristou v. City of Jacksonville, 405 U.S. 156, 163-64, 171 (1972); see also infra notes $51-60$ and accompanying text.

13. Wyche, 619 So. $2 \mathrm{~d}$ at 234; see also Debbie Salamone, Florida Supreme Court Overturns Loitering Laws in Sanford, Tampa, OrLando Sentinel. Trib., Mar. 26, 1993, at A1.

14. City of Tacoma v. Luvene, 827 P.2d 1374, 1379, 1384 (Wash. 1992) (upholding a Tacoma, Washington ordinance that proscribed loitering in a manner and under circumstances manifesting a purpose to engage in prohibited drug-related activity).

15. For the sake of both brevity and clarity, I have limited my discussion to these two cballengcs. Depending on the particular law, other possible challenges to loitering laws may be bascd on the Equal Protection Clause, see Wyche v. State, 619 So. 2d 231, 238 (Fla. 1993) (Kogan, J., concurring), the Fourth Amendment protection against unreasonable searches and seizures, see City of Milwaukee v. Nelson, 439 N.W.2d 562, 563 (Wis. 1989), cert. denied, 493 U.S. 858 (1989), and the Eighth Amendment prohibition against cruel and unusual punishment, see Farber v. Rochford, 407 F. Supp. 529, 533 (N.D. Ill. 1975).

16. See Connally v. General Constr. Co., 269 U.S. 385, 391 (1926).

17. Papachristou v. City of Jaeksonville, 405 U.S. 156, 162 (1972). For commentators' perspectives on the void-for-vagueness doctrine, see generally HERBERT L. PACKER, THE LIMITS OF THE Criminal Sanction 72, 78, 93-96, 290-92 (1968); David S. Bogen, First Amendment Ancillary Doctrines, 37 MD. L. REv. 679, 714-726 (1978); Rex A. Collings, Jr., Unconstitutional UncertaintyAn Appraisal, 40 Cornell L.Q. 195 (1955); Joln C. Jeffries, Jr., Legality, Vagueness, and the Construction of Penal Statutes, 71 VA. L. Rev. 189 (1985); Anthony G. Amsterdam, Note, The Void for Vagueness Doctrine in the Supreme Court, 109 U. PA. L. REv. 67 (1960); Mark A. Ricbard, Comment, The Void-for-Vagueness Doctrine in Village of Hoffman Estates v. The Flipside, Hoffman Estates, Inc.: Revision or Misapplication?, 34 Hastangs L.J. 1273 (1983).

18. Thomhill v. Alabama, 310 U.S. 88, $97-98$ (1940). For commentators' perspectives on the overbreadth doctrine, see generally Bogen, supra note 17, at 705-14; Ricbard H. Fallon, Jr., Making Sense of Overbreadth, 100 Y ALE L.J. 853 (1991); Henry P. Monaghan, Overbreadth, 1981 SuP. CT. REv. 1; Jeffrey M. Shaman, The First Amendment Rule Against Overbreadth, 52 TEMP. L.Q. 259 (1979); J.W. Torkc, The Future of First Amendment Overbreadth, 27 VAND. L. REv. 289 (1974); Note, The First Amendment Overbreadth Doctrine, 83 HARv. L. REv. 844 (1970); Note, Overbreadth Review and the Burger Court, 49 N.Y.U. L. Rev. 532 (1974). 
This Comment demonstrates that the primary purposes of the vagueness and overbreadth doctrines are: (1) to prevent a "chilling effect" on generally innocent or constitutionally protected activity, and (2) to prevent the arbitrary and discriminatory enforcement of laws. Traditional loitering statutes were highly susceptible to discriminatory enforcement and could proscribe and deter protected activity. Vagueness and overbreadth challenges to such traditional statutes have severely limited the scope of activities that loitering laws may reach. Because Chicago's ban on gang loitering exceeds these limits, it is unlikely to survive constitutional attack.

Part I of this Comment discusses the background of the Ordinance and loitering laws in general. Part II discusses the vagueness and overbreadth doctrines. This section examines the tests and nnderlying rationales of both doctrines in detail, noting in particular the similarity of the two doctrines in First Amendment cases. Based upon this similarity, Part III presents a unified approach for analyzing vagueness and overbreadth in loitering laws.

Part IV applies this approach to the Ordimance, and concludes that the Ordinance is unlikely to survive challenges based on these doctrines. Part $\mathrm{V}$ proposes an alternative version of the Ordinance that should withstand vagueness and overbreadth challenges, but emphasizes that even this version presents practical problems in enforcement. The Comment concludes with some thoughts on the current utility of loitering laws as a tool for crime prevention.

\section{I \\ BACKGROUND}

This Part begins by examining the Chicago City Council's intent in enacting the Ordinance. Next, the history of loitering laws is traced from their original use im early English law to their application in the Umited States as a means of crime prevention. Finally, recent changes in the scope of loitering laws are discussed.

\section{A. The Ordinance}

The avowed purpose of the Ordinance is to preserve Chicago's streets and other public places so that the public may use such places without fear. ${ }^{19}$ The City Council passed the Ordinance on the basis of several legislative findings. ${ }^{20}$ The City Council found that increasing criminal gang

19. See Chicago, IlL., Mun. Code § 8-4-015 (1993) (preamble).

20. During two days of committee hearings, Chicago residents offered compelling testimony that they felt trapped in their homes because of the fear of gang violence. Anti-gang Law Isn't the Answer, CHI. TRIB., May 20, 1992, § 1, at 16 . Council members also emphasized the problem of gang intimidation in their comments to the press. For example, Alderman Ed Smith said that "[i]t's difficult for ordinary people to even come out of their homes because of the shooting and gang activity." Johnson, supra note 3. Similarly, Alderman Patrick O'Counor stated that "[p]eople in the ncighborhoods are growing increasingly upset that the rights of criminals are protected so they can continue terrorizing these communities." John Kass, Old Tactic Sought in Crime War, CHr. TrRB., May 
activity was largely responsible for a higher murder rate and increased violent and drug-related crimes in the city. ${ }^{21}$ The City Council also found that criminal street gangs estabhsh control over identifiable areas by loitering in those areas and intimidating others from entering them. ${ }^{22}$ In addition, the City Council determined that loitering by criminal street gang members creates a justifiable fear for the safety of persons and property in the area because of the violence, drug-dealing, and vandalism often associated with such activity. ${ }^{23}$ Finally, the City Council found that by committing no offense punishable under existing law when police are present, criminal street gangs are able to maintain control over identifiable areas while avoiding arrest. ${ }^{24}$ Based on these findings, the City Council concluded that an aggressive measure was necessary to preserve the city's streets and other public places so that the public may use such places without fear.

Since the Ordinance was enacted, both the American Civil Liberties Union and the Cook County Public Defender's Office have challenged its constitutionality in the Illinois courts. ${ }^{25}$ Thus far, inost trial court judges have held that the Ordinance is unconstitutional. ${ }^{26}$

$15,1992, \S 2$, at 1; see also Robert Davis, Special Units to Police Loiterers, City Wants to Make New Anti-Gang Law Hold Up in Court, Chr. TRrB., June 19, 1992, § 2, at 3.

21. ChICAGo, IlL., Mun. Code § 8-4-015 (preamble).

22. Id.

23. Id.

24. Id. at 4 .

25. Jerry Thornton, City to Fight for its Gang Loitering Law, CH. TRæB., September 30, 1993, § 2,

26. See, e.g., City of Chicago v. Gonzales, No. 94-MCl-392418 (Ill. Cir. Ct. February 23, 1995) (Judge Gene Willens holding the Ordinance unconstitutional); City of Chicago v. Preshon, No. 93-MCl217630 (IIl. Cir. Ct. January 25, 1995) (Judge Janice McGaughey holding the Ordinance unconstitutional); City of Chicago, No. 94-MC1-361275 (I1l. Cir. Ct. December 23, 1994) (Judge Consuelo Bedoya holding the Ordinance unconsitutional); City of Chicago v. Pineda, No. 94-MCl290636 (11l. Cir. Ct. Sept. 2, 1994) (Judge James Linn holding the Ordinance unconstitutional as applied to non-gang members); City of Chicago v. Heard, No. 94-MC1-31349l (Ill. Cir. Ct. Mar. 24, 1994) (Judge Lawrence Fox holding the Ordinance unconstitutional); City of Chicago v. Dieguez, No. 94MCl-234376 (Ill. Cir. Ct. Mar. 24, 1994) (Judge John Scotillo holding the Ordinance unconstitutional); City of Chicago v. Radcliffe, No. 93-MCl-339427 (Ill. Cir. Ct. Feb. 7, 1994) (Judge Daniel Gilespie holding the Ordinance unconstitutional); City of Chicago v. Pipes, No. 93-MCl-351099 (Ill. Cir. Ct. Feb. 2, 1994) (Judge Judy Mitchell-Davis holding the Ordinance unconstitutional); City of Chicago v. Mazeika, No. 93-MCl-240542 (Ill. Cir. Ct. Dec. 7, 1993) (Judge Wendell Marbley holding the Ordinance unconstitutional); City of Chicago v. Round, No. 92-MCI-424444 (Ill. Cir. Ct. Oct. 7, 1993) (Judge Saul Perdomo holding the Ordinance unconstitutional); City of Chicago v. Youkhana, No. 93MCI-293363 (Ill. Cir. Ct. Sept. 29, 1993) (Judge Thaddeus Kowalski holding the Ordinance unconstitutional). But see City of Chicago v. Stigger, No. 94-MC1-307589 (Ill. Cir. Ct. October 21, 1994) (Judge Ronald Davis holding the Ordinance constitutional); City of Chicago v. Avilar, No. 92MC1-376001 (Ill. Cir. Ct. June 10, 1993) (Judge William O'Malley holding the Ordinance constitutional). These citations were kindly provided by Cook County Public Defender Lee Carson.

The city has appealed Judge Thaddeus Kowalski's ruling holding the Ordinance unconstitutional. On March 7, 1995, an llinois Appellate Court panel heard oral arguments. The panel took the matter under advisement. Uphold Anti-Gang Law, Court Urged, Cr. DAIlY L. BurL., March 7, 1995, at 1. 


\section{B. The Origin of Loitering Laws}

Unlike the acts comprising most common-law crimes, loitering is not universally considered immoral. To "loiter" is defined as "[t]o be dilatory; ... to stand around or move slowly about; to stand idly around; to saunter; to lag behind; to linger or spend time idly."27 To be "dilatory" is to be characterized by procrastination, ${ }^{28}$ and "idle" is often synonymous with lazy. ${ }^{29}$ Thus, loitering is often associated with delay and laziness, two forms of behavior that have never been well regarded in American culture. On the other hand, loitering is also associated with positive values like freedom and independence. Strolling, wandering, and other similar behaviors have been praised in songs like "The Happy Wanderer" and "Waltzing Maltida," and in the writings of Carl Sandburg, Robert Louis Stevenson, Henry David Thoureau, and Walt Whitman. ${ }^{30}$ Courts have generally taken the view that words like "loiter," "idle," and "loaf" imply no wrongdoing or misconduct. ${ }^{31}$

Given society's conflicting perceptions of loitering, the existence of laws proscribing loitering can perhaps be best explained as an outgrowth of early English vagrancy laws. ${ }^{32}$ Mark Malone ${ }^{33}$ and Caleb Foote ${ }^{34}$ detail the history of these laws; what follows is a brief summary of their accounts.

The breakup of feudalism and the depopulation caused by the Black Death created a labor shortage in England. As a result, landowners offered higher wages to increase their depleted work forces and laborers began to travel the country offering their services to the highest bidder. ${ }^{35}$ In response, Parliament passed the Statutes of Labourers in 1349-50, compelling laborers to remain in certain areas and establishing a fixed wage. ${ }^{36}$ In

27. Black's Law Dictionary 651 (6th abridged ed. 1991); see also Barron's Law Dictionary 283 (3d ed. 1991) (defining loiter as "to linger idly by; to move slowly about; to be dilatory, particularly in a public place, around a school, or near a transportation facility').

28. See Webster's ThIRd New INTERnational Dictionary 633 (1976).

29. See id. at 1124 .

30. See Papachristou v. City of Jacksonville, 405 U.S. 156, 164 (1972); William O. Douglas, Vagrancy and Arrest on Suspicion, 70 YALE L.J. 1, 3 (1960).

31. See, e.g., Hawaii v. Anduha, 48 F.2d 171, 173 (9th Cir. 1931); People v. Diaz, 151 N.E.2d 871,872 (N.Y. 1958); City of Seattle v. Drew, 423 P.2d 522, 524 (Wasl. 1967). The court in Anduha noted that "the majority of mankind spend a goodly part of their waking hours in whiling or idling the time away, and much of that time is spent on public streets and highways and in public places." 48 F.2d at 173 .

32. Loitering should not be confused with "vagrancy," which is a general term for a class of minor offenses that often includes "loitering." See Black's LAw DictionaRY, supra note 27, at 1075 (listing the definition of vagrancy in the Kansas Criminal Code which encompasses loitering); I.J. Schiffres, Annotation, Validity of Vagrancy Statutes and Ordinances, 25 A.L.R.3d 792, 797 (1969) (explaining that statutes have used as many as $\mathbf{3 0}$ different definitions of vagrancy). This Comment is limited to loitering laws. It does not discuss vagrancy laws whose constitutionality is generally even more suspect because of the greater range of conduct involved. See id.

33. Mark Malone, Homelessness in a Modern Urban Setting, 10 FordhaM URB. L.J. 749 (1982).

34. Caleb Foote, Vagrancy-Type Law and Its Administration, 104 U. PA. L. Rev. 603 (1956).

35. Malone, supra note 33, at 754 n.l6.

36. Id. 
1530, able-bodied vagrants who did not offer themselves for work were subjected to such penalties as whipping "till his body be bloody," scourging, and bodily mutilation. ${ }^{37}$ Thus, initially, vagrancy and loitering statutes had an economic rationale. ${ }^{38}$

The focus of these laws soon shifted to crime prevention. Lack of work or poor working conditions continually forced laborers to remain inobile until "the roads of England were crowded with inasterless men and their families." 39 In order to prevent these persons from supporting theinselves through lives of crime, Parliament passed laws like the "Slavery Acts" which provided for two years' enslavement for anyone who "liveth idly and loiteringly, by the space of three days." 40

\section{Loitering Laws in the United States}

Sinilar laws soon made their way to Amcrica under "the theory that society must have a means of removing the idle and undesirable from its midst before their potential for criminal activity is realized."41 For exa1nple, "paupers" and "vagabonds" were excluded from the Privileges and Immunities Clause of the Articles of Confederation and its promise of "free ingress and egress to and from any other state."42 During the Nineteenth Century, the Supreme Court noted that it is " 'as competent and as necessary for a state to provide precautionary measures against the moral pestilence of paupers, vagabonds, and possibly convicts, [sic] as it is to guard agamst the physical pestilence ...." "'43

Crime prevention continues to be the policy behind most loitering laws in the Umited States. For example, a Florida statute forbids loitering "at a time or in a manner not usual for law-abiding individuals, under circunstances that warrant a justifiable and reasonable alarm or iminediate concern for the safety of persons or property in the vicinity." ${ }^{\text {"4 }}$ A Salt Lake City ordinance proscribes loitering under "circumstances which justify suspicion that [the loiterer] nay be engaged im or about to engage in a crime." 45

Two cominon targets of loitering laws ainied at crime prevention are prostitutes and drug dealers or users. For example, a Seattle mumcipal ordinance prohibits "prostitution loitering," which is defined to mclude

\footnotetext{
37. Id.

38. Id. at 754.

39. Foote, supra note 34, at 615-16 (internal quotation omitted).

40. Malone, supra note 33, at 754 n.17 (internal quotation omitted).

41. Id. at $755-56$.

42. Foote, supra note 34, at 616 (internal quotation omitted).

43. Id. (quoting City of New York v. Miln, 36 U.S. (11 Pet.) 102, 142-43 (1837)).

44. State v. Ecker, 311 So. 2d 104, 106 (Fla. 1975) (upholding the ordinance), cert. denied, 423
} U.S. 1019 (1975).

45. Salt Lake City v. Savage, 541 P.2d 1035, 1036 (Utah 1975) (upholding the ordinance), cert. denied, 425 U.S. 915 (1976). 
repeatedly approaching a passersby or motorist in a public place with the imtent to solicit, mduce, entice or procure another to commit prostitution. ${ }^{46}$ Similarly, an Akron, Ohio ordinance proscribes loitering in a manner and under circumstances manifesting a purpose to engage in drug-related activity. ${ }^{47}$

Other loitering laws have been directed at the obstruction of passage or prevention of free access. A Syracuse, New York ordinance provided that "no person shall loiter in or around public buildings or obstruct corridors, stairways or doorways, so as to prevent free access by members of the public, officers or employees." ${ }^{\text {"48 }}$ Sucl laws are often invoked during protests and demonstrations. For example, a Michigan State University student who took part in a sit-in was convicted under an ordinance prohibiting loitering that obstructed free and uninterrupted passage. ${ }^{49}$

Finally, local governments have also used loitering laws to bring under police control persons who, although not traditionally considered criminals, were nonetheless considered undesirable. An excellent example of this type of law was a Louisville, Kentucky ordinance that provided that any person without visible means of support or who is unable to give a satisfactory account of himself found loitering or strolling im any street or public place, or around any commercial establishment, or conducting himself in a lewd or lascivious manner, would be subject to punishinent. ${ }^{50}$

\section{General Loitering Laws versus "Loitering Plus" Laws}

Since the early 1970s, loitering laws in the United States have undergone significant change. In 1972, the Supreme Court strongly indicated that laws that proscribe mere loitering are unconstitutional. ${ }^{51}$ As a result, local governments have had to narrow the scope of their loitering laws.

In Papachristou v. City of Jacksonville, eight defendants were convicted in a Florida Municipal Court of violating a Jacksonville vagrancy ordinance. ${ }^{52}$ The challenged ordinance proscribed a long list of conduct that encompassed "persons wandering or strolling around from place to place without any lawful purpose or object" and "habitual loafers."

46. State v. VJW, 680 P.2d 1068, 1070 (Wash. Ct. App. 1984) (upholding the ordinance), rev. denied, 102 Wash. 2d 1001 (1984).

47. City of Akron v. Holley, 557 N.E.2d 861, 864, 867 (Ohio Mun. Ct. 1989) (upholding the ordinance).

48. People v. Baer, 270 N.Y.S.2d 434, 435, 437 (N.Y. County Ct. 1965) (upholding the ordinance) (emphasis omitted).

49. People v. Deutsch, 172 N.W.2d 392, 393, 397 (Mich. Ct. App. 1969) (upholding the ordinance).

50. Baker v. Bindner, 274 F. Supp. $658,663-64$ (W.D. Ky. 1967) (invalidating the ordinance as vague and overbroad).

51. See Papachristou v. City of Jacksonville, 405 U.S. 156, 171 (1972).

52. Id. at 156.

53. Id. at $156 \mathrm{n} .1$. The Jacksonville ordinance provided: 
defendant named Heath, and an unnamed codefendant ${ }^{54}$ were arrested when they drove up to the residence of Heath's girlfriend..$^{55}$ Police officers were already present, and were arresting another man. Heath and his companion apparently saw this, and began backing out of the driveway. The officers signaled them to stop, and asked them to exit the car. When they did, they and their vehicle were searched. ${ }^{56}$ Although no incriminating evidence was found, both were arrested. Heath was charged under the vagrancy ordinance as a "common thief" because he was reputed to be a thief. His compamion was charged with "loitering" for standing in the driveway, although he was only doing so at the officers' command.57

The Supreme Court held that the ordinance was void for vagueness under the Due Process Clause of the Fourteenth Amendinent. The Court felt that the ordinance did not give a person of ordinary intelligence fair notice that his contemplated conduct is forbidden by the statute, and that the ordinance encouraged arbitrary and erratic arrests and convictions. ${ }^{58}$ Interpreting the ordinance literally, the Court apphed it to hypothetical situations: " $[\mathrm{P}]$ ersons able to work but habitually living upon the earnings of their wives or minor children' may also embrace uneinployed people out of the labor market, by reason of a recession or diseinploycd by reason of technological or so-called structural displacements." 59 Thus, the Court concluded that the ordinance criminalizes actions that are usually considered innocent. ${ }^{60}$

In an attempt to meet constitutional objections, local governments have responded by narrowing the scope of their loitering laws. Instead of proscribing mere loitering, these "loitering plus" laws ${ }^{61}$ require additional elements such as a lack of apparent or sufficient purpose for loitering, fail-

\footnotetext{
"Rogues and vagabonds, or dissolute persons who go about begging, common gamblers, persons who use juggling or unlawful games or plays, common drunkards, common night walkers, thieves, pilferers or pickpockets, traders in stolen property, lewd, wanton and lascivions persons, keepers of gambling places, common railers and brawlers, persons wandering or strolling around from plaee to place without any lawful purpose or object, habitual loafers, disorderly persons, persons neglecting all lawful business and habitually spending their time by frequenting houses of ill fame, gaming houses, or places where alcoholic beverages are sold or served, persons able to work but habitually living upon the earnings of their wives or minor children shall be deemed vagrants and, upon conviction in the Municipal Court shall be punished [by 90 days' imprisonment, a $\$ 500$ fine, or both]."
}

Id. (quoting Jacksonville, Fla. Ordinance Code § 26-57).

54. The Supreme Court's opinion was based on five consohidated cases. Id. at 158.

55. Id. at 160 .

56. Id.

57. Id.

58. Id. at 162 (citing United States v. Harriss, 347 U.S. 612,617 (1954); Thomhill v. Alabama, 310 U.S. 88 (1940); Herndon v. Lowry, 301 U.S. 242 (1937)).

59. Id. at 163 (footnote omitted).

60. Id.

61. Middleton, supra note 1. Roger L. Couner, Executive Director of American Alliance for Rights and Responsibilities, a Washington, D.C. public interest group, admits that earlier loitering ordinances allowed misuse of police power. But Conner supports the new generation of "loitering plus" laws, arguing that "[w]hat's at stake is the life of the community as a community." Id. 
ure to give a satisfactory explanation for loitering, failure to obey a police order to disperse, some criminal mens rea, the obstruction of free passage, a threat to the public safety, or that the defendant be a member of a certain limited class of persons. ${ }^{62}$

Chicago's Ordinance is an example of a "loitering plus" law. Under the Ordinance, a violation requires more than just idly standing around. ${ }^{63}$ "Loiter" is defined by the Ordinance as "to remain in any one place with no apparent purpose." 64 The Ordinance also requires that at least two people loiter and that at least one of these person be a "crimmal street gang meinber."65 Furthermore, a violation does not occur until such persons disobey a police order to disperse and remove themselves from such area. ${ }^{66}$

Whether this or any other loitering plus law can survive constitutional challenge based on vagueness and overbreadth is a complex question. The next Section attempts to unravel these doctrines in an effort to discover what factors affect a court's determination of whether a law is overly vague or overbroad. Part III presents an approach for analyzing vagueness and overbreadth in loitering laws.

\section{II}

\section{The Vagueness AND OverbReadth Doctrines}

\section{A. Vagueness}

Theoretically, the void-for-vagueness doctrine emanates froin the due process requirements of the Fifth and Fourteenth Amendments. ${ }^{67}$ Due pro-

62. See, e.g., Farber v. Rochford, 407 F. Supp. 529, 530 (N.D. III. 1975) (discussing an ordinance making it unlawful for any habitual drunkard, any person known to be a narcotic addict or prostitute, or any person previously convicted of a felony to assemble or congregate in public with other persons of the foregoing classes); Kirkwood v. Loeb, 323 F. Supp. 611, 613 (W.D. Tenn. 1971) (discussing an ordinance that criminalized congregating or loitering after a police order to move on); Watts v. State, 463 So. 2d 205, 205 n.1 (Fla. 1985) (discussing an ordinance forbidding loitering or prowling "in a place, at a time or in a manner not usual for law-abiding individuals, under circumstances that warrant a justifiable and reasonable alarm or immediate concern for the safety of persons or property"); Henrichs v. Hildreth, 207 N.W.2d 805, 806 (Iowa 1973) (discussing an ordinance making it unlawful for persons "to collect, assemble, or group together, and after [doing so] . . to stand, or loiter . . . to the hindrance or obstruction to free passage of any person or persons"); State v. Richard, 836 P.2d 622, $623 \mathrm{n} .2$ (Nev. 1992) (discussing an ordinance that prohibited loitering on private property when the loiterer has no "lawful business"); City of Akron v. Holley, 557 N.E.2d 861, 864 (Ohio Mun. Ct. 1989) (discussing an ordinance construed to require a purpose of engaging in prohibited drug-related activity and some overt act manifesting such purpose); City of Bellevue v. Miller, 536 P.2d 603, 605-06 (Wash. 1975) (discussing an ordinance that allowed the loiterer to explain his or her conduct to arresting officer).

63. Compare supra text aceompanying note 27 with CHCAGo, ILl., MUN. CoDE § 8-4-015(c)(1), supra note 2.

64. ChICAGo, Ill., Mun. Code § 8-4-015(c)(1), supra note 2.

65. Chicago, Ill., Mun. Code § 8-4-0I5(a), supra note 2.

66. Id.

67. The Fifth Amendment, which applies to the federal government, provides that "[n]o person shall be ... deprived of life, liberty, or property, without due process of law." U.S. CoNST. amend. V. The Fourtcenth Amendment, which applies to the states, provides that "[n]o State shall ... deprive any person of life, liberty, or property, without due process of law." U.S. CoNST. amend. XIV, $\S 1$. 
cess requires that laws which prohibit certain conduct clearly define the prohibited behavior. ${ }^{68}$ In the classic formulation of the vagueness test, the Court held that "a statute which either forbids or requires the doing of an act in terms so vague that inen of common intelligence inust necessarily guess at its ineaning and differ as to its application, violates the first essential of due process of law." $" 69$ Thus, according to the Court, the vagueness doctrine requires that a criminal statute provide "notice." That is, the statute inust define the criminal offense with sufficient definiteness so that individuals can understand what conduct is prohibited. ${ }^{70}$

However, John Calvin Jeffries, Jr. lias deinonstrated that notice is not a persuasive rationale for the application of the vagueness doctrine to penal statutes. $^{71}$ While punishment without notice may appear unfair, criminal punishment does not require, and is often imposed on a defendant, without actual notice that his or her conduct is prohibited. ${ }^{72}$ First, the state provides sufficient notice to the public merely by publishing a statute. ${ }^{73}$ Second, ascertaining the nature and extent of the law often requires difficult legal research and interpretation. ${ }^{74}$ Finally, unless the state is responsible for a defendant's error, iguorance of the law is no defense. ${ }^{75}$ In short, given the lack of actual notice required under our legal system, a rationale of fair warning makes little sense.

Far more persuasive as a rationale for the application of the vagueness doctrine is the prevention of arbitrary or discriminatory law enforcement. ${ }^{76}$ For example, Jeffries notes that the vagueness doctrine furthers the socalled "rule of law."77 Under this legal principle, decisions of governmental authorities "should be made by the application of known principles or laws without the intervention of diseretion."78 When a law is vague, the primciples governing the decisions of authorities are not known. Rather, law enforcement authorities will differ as to the purpose and application of a vague law. Thus, by limiting vagueness in the law, the vagueness doctrine reinforces the rule of law.

Jeffries notes that, in particular, the vagueness doctrine allows courts to reach hidden bias or prejudice in law enforcement. The rule of law seeks to prevent officials from relying on illegitimate criteria. ${ }^{79}$ In our society,

68. See United States v. Harriss, 347 U.S. 612, 617 (1954).

69. Connally v. General Constr. Co., 269 U.S. 385, 391 (1926).

70. Kolender v. Lawson, 461 U.S. 352, 357 (1983).

71. See Jeffries, supra note 17, at 205-12 (arguing that notice does not operate as a major component of the vagueness doetrine).

72. See id. at 205-07.

73. Id. at 207.

74. Id. at 207-08.

75. Id. at 208.

76. Kolender v. Lawson, 461 U.S. 352, 357-58 (1983).

77. Jeffries, supra note 17 , at 215 .

78. BLACK's LAW DictionaRY, supra note 27, at 925-26.

79. Jeffries, supra note 17 , at 212. 
the legitimacy of criteria is often based on the concept of equality. The Constitution prohibits discrimination on the basis of race, ethnicity, religion, for some purposes political affiliation, and for most purposes gender. These prohibitions are part of a constitutional commitment to "the equal protection of the laws." $\$ 80$ By definition, bias and prejudice are inconsistent with evenhanded administration of the law. When a vague statute is applied in a discriminatory inanner, the rule of law breaks down because the statutory language provides no indication of the discriminatory criteria that law enforcement officers are using. ${ }^{81}$ Thus, by permitting courts to invalidate vague statutes, the void-for-vagueness doctrine allows the judiciary to reacls hidden bias or prejudice in law enforcement.

Another rationale for the vagueness doctrine is to provide "breathing space" for First Amendment freedoms. According to one commentator, vagueness " "has developed as an instrumental doctrine rather than one having independent force. [It is invoked] when certain values that the Court is particularly interested in protectimg ... seem to be threatened." "82 Both the Court and commentators liave recognized that First Amendment freedoms are just sucli an interest. ${ }^{83}$ According to the Court, the danger of an overly vague statute is not merely its unnecessary application to protected activity, but also the "chilling effect" that it lias on the public's willingness to exercise constitutional rights. ${ }^{84}$ Because a person does not know whether his conduct will ultimately be held to be constitutionally protected, lie may declime to exercise his First Amendment rights. Thus, the threat of sanctions may deter some people from engaging in activity that the statute could not constitutionally reach. ${ }^{85}$

80. See U.S. ConsT. amend. XIV, $\S 1$; Jeffries, supra note 17, at 213.

81. Jeffries, supra note 17 , at 213.

82. David W. Gartenstein \& Joseph F. Warganz, Note, RICO's "Pattern" Requirement: Void For Vagueness?, 90 Colum. L. REv. 489, 506 n.129 (1990) (quoting PACKER, supra note 17, at 94) (alterations in original).

83. See NAACP v. Button, 371 U.S. 415, 432 (1963); JoHn E. NowAK \& RoNald D. Rotunda, Constitumonal LAW $\S 16.9$ (4th ed. 1991); Amsterdam, supra note 17, at 7 .

84. Button, 371 U.S. at $432-33$ ("[First Amendment] freedoms are delicate and vulnerable, as well as supremely precious in our society. The threat of sanctions may deter their exercise almost as potently as the actual application of sanctions.").

85. Anthony Amsterdam has suggested a third rationale for the vagueness doctrine: compensating for practical difficulties in judicial review. See Amsterdam, supra note 17, at 89 . First, because of appellate courts' limited power to review findings of fact, the apparent nature and scope of a law's enforcement must be made to reflect its actual enforcement. Id. Second, because the sheer volume of cases makes it impossible for courts to review law enforcement practices on a case by case basis, a certain rcgularity in law enforcement is required. Id. If a statute provides too much discretion, it is likely to function erratically and result in a siguificant number of impermissible applications that escape detection or review by an appellate court. Id. at 90 . By insisting upon concrete statutory language, the vagueness doctrine helps courts to limit the scope of such discretion and ensure regularity in law enforcement. See id. at $89-90$. 


\section{B. Overbreadth}

A statute is overbroad if, in addition to proscribing activities that are not constitutionally protected, it also sweeps within its coverage activities that are protected by the First Amendment. ${ }^{86}$ The main rationale for this prohibition is to provide "breathing space" for First Amendment freedoms. Like a law that is overly vague, a law that is overbroad may have a "chilling effect" on the public's willingness to exercise its constitutional rights. Specifically, the mability to discern whether the law will be invoked against one's activity and whether such activity will ultimately be protected by the courts will cause people to forego exercise of their First Amendment rights. ${ }^{87}$ In addition, like the vagueness doctrine, the overbreadth doctrine is concerned with arbitrary or discriminatory enforcennent. ${ }^{88}$

Under the original formulation of the overbreadth doctrine, a statute was unconstitutionally broad if, in addition to proscribing activities that are not constitutionally protected, it reached speech or conduct that is protected by the First Amendment. ${ }^{89}$ If a court concluded that a law extended too far in its coverage of First Amendment activities, that law would be stricken down as overbroad, regardless of the state's interest in the law..$^{90}$

However, the overbreadth doctrine was substantially curtailed by the Court in Broadrick v.. Oklahoma. ${ }^{91}$ In Broadrick, the Court distinguished between statutes governing pure speech and those primarily regnlating conduct. ${ }^{92}$ In the former, the Court did not modify the overbreadth doctrine. But for statutes governing conduct, even where the conduct happens to have an expressive element, the majority believed that for facial invalidation to be appropriate "the overbreadth of a statute must not only be real, but substantial as well, judged in relation to the statute's plainly legitimate sweep."93 Thus, for conduct cases, Broadrick transformed the overbreadth analysis from a mechanical method of adjudication to a qualitative evaluation of a law's inpermissible applications in light of its permissible scope.

86. Thornhill v. Alabama, 310 U.S. 88, 97 (1940).

87. Gooding v. Wilson, 405 U.S. 518, 521 (1972). In Arnett v. Kennedy, 416 U.S. 134 (1974), Justice Marshall commented:

That this Court will ultimately vindicate an employee if his speech is constitutionally protected is of little consequence-for the value of a sword of Damocles is that it hangs-not that it drops. For every employee who risks his job by testing the limits of the statute, many more will choose the cautious path and not speak at all.

Id. at 231 (Marshall, J., dissenting).

88. See NAACP v. Button, 371 U.S. 415, 435 (1963).

89. See Thornhill, 310 U.S. at 97.

90. See William J. Maffucci, Should the "Substantial Overbreadth" Doctrine Be Overhauled? The Example of Morrisette v. Dilworth, 33 Burf. L. REv. 457, 463 (1984).

91. 413 U.S. 601 (1973).

92. Id. at 615 .

93. Id. 


\section{Applying the Vagueness and Overbreadth Doctrines}

Consistent with the rationale of providing "breathing space" for First Amendment freedoms, both the vagueness and overbreadth doctrines expand the scope of review where free expression is threatened. Normally, a defendant seeking to challenge a statute on vagueness grounds must show that the statute is unconstitutionally vague as applied to her particular circumstances. ${ }^{94}$ When the statute implicates First Amendment rights, however, a challenger may prevail by showing that, applied according to its terms, the statute would violate the First Amendinent rights of persons not presently before the court. ${ }^{95}$ However, the Supreme Court has often rejected vagueness challenges altogether when it has felt that it was "plain as a pikestaff" that the defendant's conduct was proscribed. ${ }^{96}$ Nonetheless, if First Amendment rights are threatened, facial challenges are usually permissible. ${ }^{97}$

The overbreadth doctrine provides a similar exception. Normally, a litigant who is attempting to have a statute ruled unconstitutional must show that it is unconstitutional in its application to her. ${ }^{98}$ But the overbreadth doctrine also permits a challenger to prevail by showing that the statute, applied according to its terms, would violate the First Amendinent rights of other persons. ${ }^{99}$

Vagueness and overbreadth challenges to loitering laws have received this special treatment. Although loitering is not expressly protected by the First Amendment, it is conduct affectimg free speech and free movement, and, when engaged im by two or more persons, borders on the rights of association and asseinbly. In Papachristou, the Court indicated that wandering and strolling were individual freedoms worthy of protection, and allowed a facial challenge to the loitering ordinance. ${ }^{100}$ In fact, the Court

94. New York v. Ferber, 458 U.S. 747, 767 (1982); United States v. Mazurie, 419 U.S. 544, 550 (1975).

95. NAACP v. Button, 371 U.S. 415,432 (1963).

96. Williams v. United States, 341 U.S. 97, 101 (1951) (stating that it is "plain as a pikestaff" that beating a confession out of a prisoner deprives the prisoner of due process).

97. Not only does the practice of considering hypothetical applications of a statute protect First Amendment rights, it is also consistent with the rationale of compensating for practical difficulties in judicial review. Assuming a vague statute results in ad hoc enforcement, permitting a court to consider hypotheticals allows the court to examine factual situations which would otherwise be effectively unreviewable. See Amsterdam, supra note 17, at 104-05.

98. Broadrick v. Oklahoma, 413 U.S. 601, 610-11 (1973).

99. Id. at 611-12. However, a hitigant has no standing to attack legislation on overbreadth grounds where he does not claim " 'specific present objective harm or a threat of specific future harm," " Bigelow v. Virginia, 421 U.S. 809, 816-17 (1975) (quoting Laird v. Tatum, 408 U.S. 1, 13-14 (1972)), or where he challenges a criminal statute other than the one under which he is convicted, see, e.g., Colten v. Kentucky, 407 U.S. 104, 111 n.3 (1972).

100. See Papachristou v. City of Jacksonville, 405 U.S. 156, 164 (1972); see also Kirkwood v. Loeb, 323 F. Supp. 611,615 (W.D. Tenn. 1971) ("There is also the right to be upon the public streets which is broader than the right to be upon the streets to disscminate information and peaceably assemble to redress grievances."). 
considered hypothetical applications of the ordinance in holding it unconstitutionally vague. ${ }^{101}$ Since Papachristou, other courts have followed suit in allowing relaxed standing in vagueness and overbreadth challenges to loitering statutes. ${ }^{102}$

III

\section{ANALYZING LOITERING LAWS FOR VAGUENESS AND OVERBREADTH}

Vagueness and overbreadth in loitering laws inay be analyzed under a single approach. In this context, both doctrines are concerned with preventing a chilling effect on the exercise of First Amendment rights and preventing arbitrary and discriminatory enforceinent. A loitering ordinance's chilling effect and potential for arbitrary and discriminatory enforceinent can be tested by determining the degree to which the statutory language sweeps within its coverage activity that is generally innocent or constitutionally protected. Although the vagueness doctrine is also purportedly designed to provide notice, this rationale is unpersuasive. ${ }^{103}$ Accordingly, the Court's notice-based "inen of common intelligence" test is not dispositive. ${ }^{104}$

\section{A. Notice}

In general, the notice that a statute provides is of little significance. As noted by Professor Jeffries, Kolender v. Lawson ${ }^{105}$ amply illustrates the unpersuasiveness of the notice rationale. ${ }^{106}$ After being detained or arrested on approximately fifteen different occasions under a California loitering statute, Edward Lawson brought a civil action seeking a declaratory judginent that the statute was unconstitutional. ${ }^{107}$ The statute at issue made it a misdemeanor for anyone loitering without apparent reason to refuse to identify himself when requested to do so by a police officer under circumstances that would "indicate to a reasonable inan that the public safety demands such identification." 108 By attaching liability only after a police officer has asked a person to identify himself and that person has refused to do so, this

101. Papachristou, 405 U.S. at 164 (noting that the ordinance "would literally embrace many members of golf clubs and city clubs").

102. See, e.g., Fields v. City of Omaha, 810 F.2d 830, 832-34 (8th Cir. 1987); ACLU v. City of Alexandria, 747 F. Supp. 324, 326-29 (E.D. Va. 1990); Farber v. Rochford, 407 F. Supp. 529, 531-35 (N.D. 1ll. 1975); Profit v. City of Tulsa, 617 P.2d 250, 251 (Okla. Crim. App. 1980).

103. See supra text accompanying notes 71-75.

104. See Laurence H. Tribe, American Constitumonal Law $\$ 12-31$ (2d ed. 1988) (discussing how vagueness closely parallels overbreadth in the First Amendment cases in that the emphasis is not on the notice provided by a statute, but rather on the statute's chilling effect).

105. 461 U.S. 352 (1983).

106. See Jeffries, supra note 17, at 217-18.

107. Kolender, 461 U.S. at 354.

108. Id. at 353 n.1. 
statute provides for explicit warning. ${ }^{109}$ Nonetheless, the Court held that the statute was unconstitutionally vague because it provided police officers with no standard for determining whether identification was credible or reliable. As such, the statute gave almost complete discretion to law enforcement. ${ }^{110}$

Similarly, in Commonwealth v. Carpenter, ${ }^{111}$ the defendant was charged under the second part of a loitering ordinance which provided that no person shall "wilfully and unreasonably saunter or loiter for more than seven minutes after being directed by a police officer to move on."112 The court held this part of the ordinance unconstitutional, stating that "mere sauntering or loitering on a public way is lawful and the right of any inan, woman, or child."113 As in Kolender, a lack of fair warning cannot explain this decision. Under the ordinance, hability only attached after the defendant refused to disperse after being requested by a police officer to do so. ${ }^{114}$

Thus, the fact that a loitering statute provides an individual with notice that his or her actions are prohibited is not dispositive. In particular, a loitering statute will not be saved by requiring, as an additional element, either a failure to give a satisfactory explanation for loitering or a failure to obey a police order to disperse.

\section{B. Innocent or Constitutionally Protected Activity}

Far more significant than the notice provided is the degree to which the statutory language sweeps within its coverage activity that is generally innocent or constitutionally protected. This factor is crucial because it determines a loitering statute's chilling effect and potential for arbitrary and discriminatory enforcement. Consistent with this rationale, the more activ-

109. See Jeffries, supra note 17 , at 217 .

110. Kolender, 461 U.S. at 358, 361; see also State v. Bitt, 798 P.2d 43, 49 (Idaho 1990) (holding that a municipal ordinance which criminalized loitering at unusual times or places, subject to an opportunity to explain identity and conduct to police officer, is void for vagueness where the sufficiency and credibility of the explanation is left to the unfettered discretion of the officer in the field); Howard v. State, 617 S.W.2d 191, 192 (Tex. Crim. App. 1979) (en banc) (holding that a loitering ordinance making it unlawful to be out at night under suspicious circumstances and without being able to give a satisfactory explanation was unconstitutionally vague); People v. Villaneuva, 318 N.Y.S.2d 167, 168, 171 (N.Y. City Ct. 1971) (holding unconstitutional a statute making it a crime to loiter in or about a place without apparent reason and under circumstances which justify suspicion that a suspect might be engaged in or about to engage in a crime, and where upon inquiry by a peace officer, the suspect refuses to identify himself or fails to give a credible account of his conduct and purposes).

111. 91 N.E.2d 666 (Mass. 1950).

112. Id. at 666 (quoting Boston, Mass., Rev. Ordnances, ch. 40, $\S 34$ (1947)).

113. Id. at 667 .

114. Id. at 666; see also City of St. Louis v. Burton, 478 S.W.2d 320, 321-23 (Mo. 1972) (holding unconstitutionally vague and overbroad an ordinance prohibiting loitering on strect comers, or around any place of amusement, or any hotel, public building or thoroughfare, and refusing to disperse or vacate such areas when requested to do so by a police officer); State v. Hudson, 274 A.2d 878, 879-80 (N.H. 1971) (invalidating an ordinance that prohibited loitering on city sidewalks, in front of bnsiness establishments, public buildings, or houses of worship, after being warned by a police officer to disperse). 
ity covered by a statute that is protected by the First Amendment or affects the exercise of First Amendment rights, the more likely it is that the statute will be found overly vague or broad. Even where the activity is not explicitly protected by the First Amendment or is only tenuously related to the exercise of First Amendment rights, if the activity is substantively innocent or represents only an insignificant infringement on the rights of others, courts often conclude that the application of crimmal sanctions to sucli activity is improper. ${ }^{115}$

In addition, courts consider the degree of generally innocent or constitutionally protected activity within a statute's coverage im determining whether the statute creates an excessive risk of arbitrary or discriminatory enforcement. First, courts are less tolerant of any possibility for arbitrary or discriminatory enforcement if the statute reaches First Amendment activity, because such activity is considered vitally important to our society. ${ }^{116} \mathrm{Sec}-$ ond, courts are more likely to find that a statute creates an excessive risk of arbitrary or discriminatory enforcement when the statute reaches a large amount of generally innocent or constitutionally protected activity. To illustrate why this is so, imagine an ordinance making it a crime to be in public. Not only is this activity innocent $\mathrm{m}$ and of itself, but such a statute would very likely be enforced in a discriminatory manner, because, obviously, every citizen who appears in public cannot be arrested. ${ }^{117}$

As a result, when the very core of the activity described by a statutethe activity clearly falling within its coverage ${ }^{118}$-is generally innocent or constitutionally protected, the statute is unlikely to survive a vagueness or overbreadth challenge. More specifically, a court is likely to find that the statute has a chillimg effect on the exercise of First Amendment rights or is likely to be enforced in an arbitrary or discriminatory manner.

In practice, courts are often not careful to distinguisli wliether the language is overly vague or simply too broad. Consider once more an ordinance that makes it a crime to be $\mathrm{m}$ public. Not only is this activity generally innocent, but the ordinance is likely to have a chilling effect on the exercise of free speecli and assembly rights, and to be enforced in an

115. See Hawaii v. Anduha, 48 F.2d 171, 172-73 (9th Cir. 1931); City of Seattle v. Jones, 488 P.2d 750, 752 (Wash. 1971). In Jones, the court stated:

"It is fundamental that no ordinance may unreasonably or unnecessarily interfcre with a person's freedom, whether it be to move about or to stand still. The right to be let alone is inviolate; interference with that right is to be tolerated only if it is necessary to protect the rights and the welfare of others."

488 P.2d at 752 (quoting City of Seattle v. Drew, 423 P.2d 522, 524 (Wash. 1967)).

116. NAACP v. Button, 371 U.S. 415, 433 (1963).

117. For an example of such a statute, see Ricks v. United States, 414 F.2d 1111, 1113 (D.C. Cir. 1968) (holding unconstitutionally vague a statute defining as a vagrant any unemployed narcotic user or convicted narcotic offender who, without visible means of support, is found in a public place and fails to give a good account of himself).

118. See Mark Kelman, Interpretive Construction in the Substantive Criminal Law, 33 STAN. L. REv. 591, 661 (1981). 
arbitrary or discriminatory manner. ${ }^{119}$ This is exactly what the vagueness doctrine seeks to prevent. However, even persons of uncommonly little intelligence can agree on the definition of being in public. Technically, the language of this ordinance is not vague, but overbroad. Substantively, however, it makes no difference whether an ordinance is held invalid under either the vagueness or the overbreadth doctrine.

\section{Mere Loitering}

The simplest category of loitering statutes are laws that proscribe mere loitering. For example, a Dunkirk, New York ordinance provided that "[n]o person shall lounge or loiter about any street or street corner."120 Not surprisingly, statutes that proscribe mere loitering were often invalidated even before the Court's decision in Papachristou. ${ }^{121}$

Such statutes reach an impermissible level of generally innocent and constitutionally protected activity. Consider the Court's analysis of the loitering ordinance in Papachristou. The ordinance criminalized "wandering or strolling around from place to place without any lawful purpose or object." ${ }^{\text {"122 }}$ This description essentially mirrors the definition of loitering. ${ }^{123}$ Given the fact that a violation of the ordinance required nothing more than mere loitering, it is not surprising that the Court felt that this core conduct was substantively innocent. ${ }^{124}$ Moreover, the Court indicated that wandering and strolling were individual freedoms worthy of protection. ${ }^{125}$ Thus, the ordinance's core activity, mere loitering, was both generally innocent and constitutionally protected activity.

In addition, statutes that criminalize mere loitering lead courts to suspect discriminatory enforcement. In Papachristou, the Court felt that the ordinance was an attempt to subject Jacksonville's "undesirables" "to police control. ${ }^{126}$ This bias could be inferred from the ordinance's derogatory descriptions that included "[r]ogues and vagabonds," "lewd, wanton

119. See supra text accompanying notes 116-17.

120. People v. Diaz, 151 N.E.2d 871, 871 (N.Y. 1958).

121. See Hawaii v. Andaha, 48 F.2d 171, 171-73 (9th cir. 1931) (invalidating an ordinance that made it unlawful to "habitually loaf, loiter, and/or idle" in public); Soles v. City of Vidalia, 90 S.E. 2d 249, 251-52 (Ga. Ct. Appl 1955) (invalidating an ordinance that made it unlawful to "idle, loiter, or loaf" in public); City of St. Louis v. Gloner, 109 S.W. 30, $31-33$ (Mo. 1908) (invalidating an ordinance that made it unlawful to "lounge, stand, or loaf" in public); State v. Caez, 195 A.2d 496, 497-98 (N.J. Super. Ct. App. Div. 1963) (invalidating an ordinance tht made it unlawful to "loiter, lounge or slcep" in public); People v. Diaz, 151 N.E. 871, 871-72 (N.Y. 1958) (invalidating an ordinance that made it unlawful to "lounge or loiter" on city streets).

122. Papachristou v. City of Jacksonville, 405 U.S. 156, 157 n.1 (1972).

123. See supra text accompanying note 27 .

124. See Papachristou, 405 U.S. at 163.

125. See supra note 100 and accompanying text.

126. See Robert C. Post, Reconceptualizing Vagueness: Legal Rules and Social Orders, 82 CALrF. L. Rev. 491, 496 (1994) (quoting Papachristou, 405 U.S. at 171). In this case, the suspected undesirables included "poor people, nonconformists, dissenters, [and] idlers." Papachristou, 405 U.S. at 170 . 
and lascivious persons," and "common railers and brawlers."127 In several instances, the Court signaled its suspicions. For exainple, with respect to statutory language defining vagrants as "[p]ersons 'neglecting all lawful business and habitually spending their time by frequenting ... places where alcoholic beverages are sold or served," "the Court commented that this "would hiterally einbrace inany inembers of golf clubs and city clubs."128 With respect to language making vagrants of " "persons able to work but habitually biving upon the earnings of their wives or minor children,' "the Court stated that this "might implicate uneinployed pillars of the community who have inarried rich wives." 129 Obviously, the Court believed that the ordinance would be applied to Jacksonville's "undesirables," but not to its middle class society.

In some statutes, the prejudice is explicit. For example, in Farber $v$. Rochford, ${ }^{130}$ the court held unconstitutional a Chicago ordinance that inade it unlawful for any habitual drunkard, any person known to be a narcotic addict or prostitute, or any person previously convicted of a felony to assemble or congregate in public with other persons of the foregoing classes. ${ }^{131}$ Thus, by its own terms, the ordinance denied certain classes the right to engage in innocent conduct. ${ }^{132}$

However, such language is not necessary to arouse a court's suspicion. ${ }^{133}$ Courts will generally suspect hidden prejudice in all loitering laws. A law that proscribes conduct in which the inajority of the population regularly engages cannot practically be enforced against all violators. Instead, law enforcennent officials are likely to target certain individuals. ${ }^{134}$ Moreover, "street-cleaning" statutes-local ordinances proscribing "trivial mis-

127. Papachristou, 405 U.S. at 156 n.1.

128. Id. at 164 .

129. Id. Professor Post has noted that "[t]he Court knew full well that the ordinance would not be applied to the local minister who loitered with his parishioners after the conclusion of services, or to the local banker who took a leisurely stroll home after a long might's work." Post, supra note 126, at 497 .

130. 407 F. Supp. 529 (N.D. Ill. 1975).

131. Id. at 530,535 .

132. Although technically not a loitering ordinance, the court compared assembling or congregating to the proscribed conduct in Papachristou, and described assembling and congregating as "'normally innocent," " id. at 533 (quoting Papachristou, 405 U.S. at 163), "perfectly defensible," id., and "ordinary conduct," id. at 534; see also Ricks v. United States, 414 F.2d 1111, 1113 (D.C. Cir. 1968) (holding void for vagueness a vagrancy statute defining as a vagrant any unemployed narcotic user or convicted narcotic offender having no lawful and visible means of support who is found in a public place and fails to give a good account of himself); Profit v. Tulsa, 6I7 P.2d 250, 251 (Okla. Crim. App. I980) (deeming overly broad an ordinance which prohibited loitering that manifests the purpose of prostitution where the ordinance made criminal "certain acts, innocent in and of themselves, if done by a 'known prostitute or known pimp' ").

133. It merely makes a court's job easier. For example, the court in Farber found that the ordinance, in addition to being overly vague, unconstitutionally criminalized status. $407 \mathrm{~F}$. Supp. at 533-34. In Profit, the court simply found the statute overbroad. 6I7 P.2d at 251.

134. See Hawaii v. Anduha, 48 F.2d 171, 173 (9th Cir. 1931). The court stated that "[i]t is almost needless to say that such an act cannot be enforced, and that no attempt will be made to enforcc it, indiscriminately." Id. 
conduct, usually with no specifically identifiable victim, and carrying minor penalties"- are highly susceptible to discriminatory enforcement against those considered socially undesirable because there is no specific victim who will monitor the statute's enforcement and because relatively minor penalties are unlikely to attract public attention. ${ }^{135}$ Finally, commentators have thoroughly chronicled the abuses of vagrancy ${ }^{136}$ and loitering laws. ${ }^{137}$ The Supreme Court has also openly acknowledged this history of abuse. ${ }^{138}$

At this point, it is worth reaffirming and reflecting upon the demise of the general loitering law. ${ }^{139}$ Under the above analysis, courts examine the degree to which the statutory language sweeps within its coverage activity that is substantively innocent or constitutionally protected. Since the Supreine Court has imdicated that loitering is generally innocent and worthy of protection, ${ }^{140}$ a statute that proscribes mere loitering necessarily reaches a high degree of innocent and protected activity. As a result, courts find that general loitering statutes have a chilling effect on people's willingness to loiter and possibly on people's willingness to exercise their First Amendnrent rights of free speech, association, and assembly. Given the high degree of innocent and protected activity reached by a general loitering statute, courts also find that such a statute creates an excessive risk of arbitrary and discrimmatory enforcement. ${ }^{141}$ This second conclusion is supported by a long history of arbitrary and discriminatory enforceinent of general loitering laws. ${ }^{142}$ In response to the demise of the general loitering law, local legislatures have passed loitering plus laws-statutes that require loitering plus one or nore additional elements. ${ }^{143}$

\section{Loitering Without a "Legitimate," "Lawful," "Apparent," or Other Similar Purpose}

Another category of loitering statutes are laws that purportedly proscribe only loitering without a "legitimate," "lawful," "apparent," or other

135. See Jeffries, supra note 17 , at 215-16.

136. Loitering laws are derived from vagrancy laws. See supra notes $35-40$ and accompanying text.

137. See, e.g., Foote, supra note 34 (detailing abuses based on a Philadelphia case study); see also Douglas, supra note 30, at 9-13 (arguing that vagrancy arrests are unconstitutional arrests on suspicion). Douglas noted that:

The persons arrested on "suspicion" are not the sons of bankers, industrialists, lawyers, or other professional people. They, like the people accused of vagrancy, come from other strata of society, or from minority groups who are not sufficiently vocal to protect themselves, and who do not have the prestige to prevent an easy laying-on of hands by the police. Id. at 13.

138. Papachristou v. City of Jacksonville, 405 U.S. 156, 166-69 (1972) (quoting Foote, supra note 34 , at 631 ).

139. See supra text accompanying notes 51-60.

140. See supra text accompanying notes $122-25$.

141. See supra text accompanying notes 115-17.

142. See supra text accompanying notes 133-38.

143. See supra text accompanying notes 61-66. 
similar purpose. However, by definition, loitering implies a lack of purpose. ${ }^{144}$ Accordingly, such statutes have been consistently found unconstitutional on their face. ${ }^{145}$ For example, in Bullock $v$. City of Dallas, the court struck down an ordinance that prohibited remaining or loitering on public premises where one's presence is unrelated to the normal activity for which the premises are made available. ${ }^{146}$ The defendant's "crime" in the case was stopping in the parking lot of a business to chat with some friends in her car. ${ }^{147}$ The court applied the ordinance's literal terms to hypothetical situations and found the ordinance could proscribe "the presence of the property owner himself; a person who has suffered a sudden injury or illness while on the premises; cake sales or kite-flying contests, etc.; or a child retrieving his baseball from a parking lot, who paused briefly to observe a beautiful sunset." 148 In holding the ordinance void on both vagueness and overbreadth grounds, ${ }^{149}$ the court described the proscribed activity as "perfectly normal, acceptable, lawful, innocent and innocuous behavior."150

\section{Loitering and a Failure to Provide Identification or a Satisfactory Explanation}

Similarly, statutes that criminalize loitering after a failure to provide identification or a satisfactory explanation will be found unconstitutional. ${ }^{151}$

144. See supra text aecompanying note 27.

145. See Papachristou v. City of Jacksonville, 405 U.S. 156, 157 n.1, 171 (1972) (invalidating an ordinance that prohibited wandering or strolling around from place to place "without any lawful purpose or object"); Kirkwood v. Loeb, 323 F. Supp. 611, 616 (W.D. Tenn. 1971) (invalidating that portion of a loitering statute that prohibited loitering "without any legitimate business or purpose"); People in Interest of C.M., 630 P.2d 593, 596-97 (Colo. 1981) (invalidating a statute that prohibited loitcring in or about school grounds without a "specific, legitimate reason"); Bullock v. Dallas, 281 S.E.2d 613, 615 16 (Ga. 1981) (invalidating an ordinance that prohibited remaining or loitering on public premises whcre one's presence is unrelated to the normal activity for which the premises are made available); State v. Richard, 836 P.2d 622, 624 (Nev. 1992) (invalidating a statute that prohibited loitering on private property when loiterer has no "lawful business"); Hayes v. Municipal Court, 487 P.2d 974, 975, 977 (Okla. Crim. App. 1971) (invalidating an ordinance that prohibited, among other things, loitering between midnight and sunrise without lawful reason); People v. Bambino, 329 N.Y.S.2d 922, 926-29 (N.Y. County Ct. 1972) (invalidating a statute that prohibited loitering without apparent reason).

Indeed, as one court noted, "the phrase "without lawful business" do[es no] more than beg the question of when loitering or loafing can themselves amount to 'lawful business.' "Scott v. District Attorney, 309 F. Supp. 833, 837 (E.D. La. 1970), (holding uneoustitutionally vague and overbroad a loitering statute), aff'd, 437 F.2d 500 (5th Cir. 1971).

146. 281 S.E.2d at $613-14$.

147. Id. at 614 .

148. Id. at 616 .

149. Id. at 615-16.

150. Id. at 614 .

151. See Kolender v. Lawson, 461 U.S. 352, 353-54, 361 (1983) (holdnig unconstitutionally vague an ordinance requiring persons who loiter to provide "credible and reliable" identification and to account for their presence); Fields v. City of Omaha, 810 F.2d 830, 834 (8th Cir. 1987) (holding unconstitutionally vague a loitering and prowling ordinance requiring a police officer, prior to any arrest, to allow a person an opportunity to identify himself and explain his presence); Scott v. District Attorney', 309 F. Supp. 833, 837 (E.D. La. 1970) (holding unconstitutionally vague and overbroad a statute criminalizing the failure to account for lawful presence), aff'd $437 \mathrm{~F} .2 \mathrm{~d} 500$ (5th Cir. 1971); 
In People v. Bambino, the court held that a person's failure "to identify himself or ... to give a reasonably credible account of his conduct and purposes," as required by the statute at issue, is imconsequential and "cannot constitute a criminal act."152 In State v. Starks, a statute defined as a vagrant a person who loiters near any structure, vehicle or private grounds without the consent of the owner and who is unable to account for her presence. ${ }^{153}$ In finding the ordinance both overly vague and overbroad, the court stated that the statute "fails to define with precision the distinction between criminal and non-criminal conduct."154

\section{Loitering Following a Police Order to Disperse}

Nor will a refusal to disperse upon police order serve to convert generally innocent conduct into conduct that can be properly proscribed. ${ }^{155}$ In Shuttlesworth v. City of Birmingham, ${ }^{156}$ a Birmingham ordinance inade it "unlawful for any person to stand or loiter upon any street or sidewalk ... after having been requested by any police officer to move on."157 The Court stated that "[1]iterally read ... this ordinance says that a person may stand on a public sidewalk in Birmingham only at the whim of any police officer of that city."158 The Court added "the mere refusal to inove on after a police officer's requesting that a person standing or loitering should do so is not enough to support the offense."159

State v. Bitt, 798 P.2d 43, 48-50 (Idaho 1990) (holding unconstitutionally vague an ordinance that criminalized loitering at unusual times or places, subject to the opportunity to explain identity and conduct to police officer); People v. Bambino, 329 N.Y.S.2d 922, 931 (N.Y. County Ct. 1972) (invalidating a loitering statute which required refusal to identify oneself or failure to give a reasonably credible account of one's conduct and purpose); City of Bellevue v. Miller, 536 P.2d 603, 608 (Wash. 1975) (holding that giving permission for a wanderer to explain his or her conduct to an arresting police officer cannot cure a loitering ordinance's vagueness); State v. Starks, 186 N.W.2d 245, 247-49 (Wis. 1971) (holding unconstitutional an ordinance defining a vagrant as a person who loiters near any structure, vehicle or private grounds without the consent of the owner and who is unable to account for his or her presence).

152. 329 N.Y.S.2d at 931 (internal quotation omitted).

153. 186 N.W.2d at 247.

154. Id. at 249.

155. See Shuttlesworth v. City of Birmingham, 382 U.S. 87,90 (1965) (stating that a Birmingham ordinance that makes it unlawful for any person to stand or loiter upon any street or sidewalk after having been requested by a police officer to move on is unconstitutional if read hiterally); Kirkwood v. Loeb, 323 F. Supp. 611, 616 (W.D. Tenn. 1971) (holding unconstitutional an ordinance criminalizing congregating or loitering atter a police order to move on); Commonwealth v. Carpenter, 91 N.E.2d 666, 666-67 (Mass. 1950) (holding unconstitutional a Boston ordinance that stated "[n]o person shall, in a street, unreasonably obstruct the free passage of foot-travellers, or willfully and unreasonably saunter or loiter for more than seven minutes after being directed by a police officer to move on').

156. 382 U.S. 87 (1965).

157. Id. at 90 (ellipsis in original).

158. Id.

159. Id. at 91 (quoting Middlebrooks v. City of Birmingham, 170 So. $2 \mathrm{~d} 424,426$ (Ala. Ct. App.), cert. denied, 170 So. $2 \mathrm{~d} 427$ (Ala. 1964)). 


\section{Loitering That Only Minimally Infringes on the Rights or Interests of Others}

Courts have also found unconstitutional statutes that criminalize loitering that does not significantly interfere with the rights or interests of others. ${ }^{160}$ The Supreme Court has held that "mere public intolerance or animosity cannot be the basis for abridgment of these constitutional freedoms [of free assembly and association]." 161 The Court also noted that ordinances that criminalize behavior simply because it annoys others openly invite discriminatory enforcement agamst those whose "ideas[,] . . . lifestyle, or ... plrysical appearance is resented by the majority of their fellow citizens." 162

Courts do regard as proper the application of criminal sanctions to loitering that significantly infringes on the rights or interests of others, or that forms part of an attempted crime. ${ }^{163}$ The Supreme Court has stated that local government is "free to prevent people from blocking sidewalks, obstructing traffic, littering streets, committing assaults, or engaging in countless other forns of antisocial conduct."164 In addition, the state may punish attempts to commit felonies or misdemeanors. ${ }^{165}$

Yet, even statutes aimed at attempted crimes or conduct that signifcantly infringes on the rights or interests of others may create a "chilling effect". or the likelihood of arbitrary or discriminatory enforcement. Specifically, these statutes may also reach activity that is generally innocent or constitutionally protected. Thus, courts must deterinime whether a statute's

160. Coates v. City of Cincinnati, 402 U.S. 611,614 (1971) (holding unconstitutionally vague and overbroad an ordinance that criminalized three or more persons assembling on a sidewalk and "annoying" passersby); Kirkwood v. Loeb, 323 F. Supp. 611, 616 (W.D. Tenn. 1971) (holding unconstitutionally vague and overbroad an ordinance that criminalized such conduct as "stand[ing] on sidewalks or street corners and mak[ing] insulting remarks to or about pedestrians' and '[i]nterfer[ing] with any person in any place by jostling against such person or unnecessarily crowding him' ") (alterations in original).

161. Coates, 402 U.S. at 615.

162. Id. at 616. With respect to the vagueness of the term "annoying," the Court statcd that the "details of the offense could no more serve to validate this ordinance than could the details of an offense charged under an ordinance suspending unconditionally the right of assembly and frce speech." Id.

163. See id. at 614; Fenster v. Leary, 229 N.E.2d 426, 428 (N.Y. 1967) (striking down a statute that proscribed conduct that did not impinge on the rights of others and was only tenuously related to crime prevention).

164. Coates, 402 U.S. at 614.

165. See Rex v. Roderick, 173 Eng. Rep. 347 (1837) (holding that it is a misdemeanor at common law to attempt to commit any felony or misdemeanor); MODEL PENAL CODE $§ 5.01$, at 362-63 cmt. 9 (1985) (noting that most American jurisdictions have enacted some form of general attcmpt statute, and that some states have adopted legislation making it an offense to attcmpt certain specific crimes); WAyNe R. LAFAve \& Austin W. SCOTT, JR., CrIMInal LAw § 6.2, at 497 (2d ed. 1986) (discussing the law of attempts); see also United States v. Snell, 627 F.2d 186, 187 (9th Cir. 1980) (affirming attempted robbery conviction) ("A conviction for attempt requires proof of culpable intent and conduct constituting a substantial step toward eommission of the crime that strongly corroborates that intent."), cert. denied, 450 U.S. 957 (1981). See also Kelman, supra note 118, at 662. 
potential illegitimate applications are too numerous "judged in relation to the statute's plainly legitimate sweep."166

Witl respect to loitering laws, any significant number of illegitimate applications will usually result im a court finding such a statute overly vague or overbroad. Specifically, where a loitering statute lias any significant number of illegitimate applications, courts will implicitly conclude, even im the absence of an obvious chilling effect, that the statute will be enforced in an arbitrary or discriminatory manner against society's undesirables. ${ }^{167}$ As a result, if a court finds that a loitering statute reaches any significant degree of generally innocent or constitutionally protected activity, it is unlikely to survive a constitutional challenge based on vagueness or overbreadtli.

\section{Loitering That Obstructs or Hinders Free Passage}

Preventing the free passage of other persons in public places represents a significant infringement of those persons' freedom of movement and is therefore properly criminalized. Moreover, the terms "obstruct" and "hinder" are not particularly vague. Accordingly, statutes that proscribe loitering which obstructs or hinders free passage have generally survived challenges based on vagueness and overbreadth. ${ }^{168}$

However, a statute that proscribes loitering that merely "tends to" hinder or impede free passage will not survive vagueness and overbreadth

166. Broadrick v. Oklahoma, 413 U.S. 601, 615 (1973); see also supra text accompanying notes 91-93. This is essentially the "substantial overbreadth" analysis. Applying such analysis to vague statutes merely underlines the similarity between the vagueness and overbreadth doctrines in the First Amendment area.

167. See supra text accompanying notes 132-38.

168. See Shuttlesworth v. City of Birmingham, 382 U.S. 87, 91 (1965) (approving as constitutional a construction of a loitering ordinance by the Alabama Court of Appeals that required the obstruction of free passage); Jobson v. City of Huntington Beach, 462 F. Supp. 774, 777 (C.D. Cal. 1978) (holding constitutionally valid a loitering ordinance construed to apply only to "persons who 'hinder or obstruct unreasonably the free passage of pedestrians,' after due warning"); State v. Kemp, 429 So. 2d 822, 824 (Fla. Dist. Ct. App. 1983) (holding constinutional a county loitering ordinance that (1) limited enforcement to acts constituting unreasonable hindrance of pedestrians or vehicles, (2) provided reasonable notice to the public by requiring either prior warning by a pohice officer or posting of a "no loitering" sign, (3) did not purport to penalize an individual's status or past conduct, and (4) contained no catchall provision); City of Des Moines v. Lavigne, 257 N.W.2d 485, 488 (lowa 1977) (holding constitutional a loitering ordinance construed to prohibit loitering only where it "obstruct[ed] persons exercising their right to freely come and go in public places"); Henrichs v. Hildreth, 207 N.W.2d 805, 806, 808 (lowa 1973) (holding constitutional a Des Moines ordinance making it unlawful for persons "to collect, assemble or group together, and after [doing so], to stand, or loiter ... to the hinderance or obstruction to free passage" of persons); People v. Deutsch, 172 N.W.2d 392, 393, 397 (Mich. Ct. App. 1969) (holding constitutional an East Lansing ordinance prohibiting loitering in public areas " "so as to obstruct the free and uninterrupted passage of the public'" and reversing defendant's conviction on other grounds); People v. Wedlow, 169 N.W.2d 145, 146-47 (Mich. Ct. App. 1969) (holding constitutional a Detroit ordimance construed to prohibit standing or idling so as to hinder or impede pedestrian traffic); see also People v. Ritchey, 181 N.W.2d 87, 88 (Mich. Ct. App. 1970) (upholding Detroit loitering ordinance discussed in Wedlow). 
challenges. In Ciccarelli v. City of Key West, ${ }^{169}$ a Florida court held unconstitutional an ordinance that prohibited loitering "so as to hinder or impede or tend to hinder or inpede the passage of pedestrians or vehicles." 170 The Ciccarelli court stated that loitering cannot be constitutionally proscribed unless it is a breach of the peace or threatens the public safety. ${ }^{171}$ Applying this test, the court found that tending to impede passage is neither a crime nor a threat to public safety. ${ }^{172}$ Thus, by including both impeding and "tending to impede," the ordinance permitted both constitutional and unconstitutional applications. In holding the entire ordinance unconstitutional, the court implicitly concluded that its unconstitutional applications were too nuinerous judged in relation to the statute's plainly legitimate sweep.

\section{Loitering for the Purpose of Engaging in Illegal Drug Activity, Prostitution, or Other Crimes}

Another category of loitering plus statutes includes laws that proscribe loitering for the purpose of engaging in illegal drug transactions, prostitution, or other crimes. While the government may legitimately strive to prevent crime, the criminalization of an atteinpted crime requires proof that (1) the accused had the specific intent to engage in a crime, and that (2) the accused committed soine overt act beyond mere preparation. ${ }^{173}$ A court will generally strike down a loitering statute that criminalizes conduct absent these two requirements even if that statute was aimed at crime prevention.

For example, several ordinances criminalize loitering in a manner and under circumstances manifesting a purpose to engage in prohibited drugrelated activity. ${ }^{174}$ Often, these ordinances include a list of circumstances such as "the person is a known unlawful drug user" or "transfer[ing] small objects or packages for currency in a furtive fashion."175 Courts usually interpret these ordinances in one of two ways. First, the ordinance may be

169. 321 So. $2 d 472$ (Fla. Dist. Ct. App. 1975).

170. Id. at 472 .

171. Id. at 474 .

172. Id.

173. See supra note 165 and accompanying text; City of Tacoma v. Luvene, 827 P.2d. 1374, 138384 (Wash. 1992).

174. See, e.g. ACLU v. City of Alexandria, 747 F. Supp. 324, 325 (E.D. Va. 1990) (discussing an Alexandria ordinance that prohibited loitering "for the purpose of engaging in the sale, gift, distribution, possession or purchase of a controlled substance"); E.L. v. State, 619 So. $2 \mathrm{~d} 252,252 \mathrm{n} .2$ (Fla. 1993) (discussing a Sanford ordinance that prohibited loitering "in a manner and under circumstances manifesting the purpose to engage in [prohibited] drug related activities"); City of Akron v. Holley, 557 N.E.2d 861, 867 (Ohio Mun. Ct. 1989) (discussing an Akron ordinance that prohibited loitcring "in a manner and under circumstances manifesting the purpose to engage in [prohibited] drug-related activity"); Luvene, 827 P.2d at 1379 (discussing a Tacoma ordinance that prohibited loitering "in a manncr and under circumstances manifesting the purpose to engage in [prohibitcd] drug-related activity").

175. E.L., 619 So. $2 \mathrm{~d}$ at 253 n.2. 
interpreted as not requiring specific criminal intent, but only requiring that the accused appear to be engaged in illegal drug-related activity, in which case the ordinance will be invalidated. ${ }^{176}$ On the other hand, the ordinance may be interpreted as requiring specific criminal intent and some overt act in addition to loitering, in which case the ordinance will be upheld. ${ }^{177}$

Similarly, several ordinances proscribe loitering in a manner and under circumstances manifesting a purpose to engage in prostitution. ${ }^{178}$ Often, these ordinances include a hist of circumstances, including the person's status as a "known prostitute" or his or her actions of "repeatedly beckon[img] to, stop[ping] or atteinpt[ing] to stop or engage[ ] passers-by in conversation." 179 Where the ordinance specifically requires, or is interpreted to

176. See City of Alexandria, 747 F. Supp. at 328 (holding unconstitutionally overbroad a loitering ordinance that equated the presence of seven circumstances with an unlawful purpose); E.L., 619 So. 2d at $253 \& \mathrm{n} .2,254$ (Kogan, J., concurring) (holding unconstitutionally vague and overbroad an ordinance that listed potentially innocent behavior as manifesting criminal intent).

177. See Holley, 557 N.E.2d at 865-66 (upholding an ordinance construed to require purpose of engaging in prohibited drug-related activity and some overt act manifesting such purpose); Luvene, 827 P.2d at 1384 (upholding an ordinance construed to require purpose of engaging in prohibited drugrelated activity and some overt act manifesting such purpose).

A third possible interpretation would be to proscribe loitering with a specific criminal intent, but without requiring an overt act in addition to loitering. See Holley, 557 N.E.2d at 865 . However, this interpretation is unlikely because it ignores the phrase "in a manner and under circumstances" which follows "loitering," as well as the non-exclusive examples of "circumstances" that are usually listed. Id. In addition, some overt act in addition to loitering is probably necessary in order to prove specific criminal intent. Id.

178. See, e.g., Johnson v. Carson, 569 F. Supp. 974, 975 (M.D. Fla. 1983) (describing a Jacksonville ordinance that prohibited loitering "in a manner and under circumstances manifesting a purpose of inducing, enticing, soliciting, or procuring another to commit an act of prostitution"); Brown v. Municipality of Anchorage, 584 P.2d 35, 36 (Alaska 1978) (describing an Anchorage ordinance that prohibited loitering "in a manner and under circumstances manifesting the purpose of inducing, enticing, soliciting or procuring another to participate in an act of prostitution"); Wyche v. State, 619 So. 2d 231, 233 n.2 (Fla. 1993) (describing a Tampa ordinance that prohibited loitering "in a manner and under circumstances manifesting the purpose of inducing, enticing, soliciting, or procuring another to commit an act of prostitution"); Profit v. City of Tulsa, 617 P.2d 250, 251 (Okla. Crim. App. 1980) (describing a Tulsa ordinance that prohibited loitering "in a manner and under circumstances manifesting the purpose of enticing, inducing, soliciting or procuring another to commit an act of prostitution"); State v. VJW, 680 P.2d 1068, 1070 (Wash. Ct. App.) (describing a Seattle ordinance that prohibited loitering if the person "remains in a public place and intentionally solicits, induces, entices, or procures another to commit prostitution"), rev. denied, 102 Wash. $2 \mathrm{~d} 1001$ (1984); City of Seattle v. Jones, 475 P.2d 790, 792 (Wash. Ct. App. 1970) (describing a Seattle ordinance that prohibited loitering "in a manner and under circumstances manifesting the purpose of inducing, enticing, soliciting or procuring another to commit an act of prostitution"), aff'd, 488 P.2d 750 (Wash. 1971); City of Milwaukee v. Wilson, 291 N.W.2d 452, 455 (Wis. 1980) (describing a Milwaukee ordinance that prohibited loitering "in a manner and under circumstances manifesting the purpose of inducing, enticing, soliciting or procuring another to commit an act of prostitution" and that required the person's conduct to demonstrate a specific intent).

179. See, e.g., Johnson v. Carson, 569 F. Supp. at 975. 
require, specific intent, it is upheld. ${ }^{180}$ Where no specific intent is required, the ordinance will be struck down. ${ }^{181}$

\section{Loitering in a Manner and Under Circumstances That Warrant a Justifiable and Reasonable Alarm}

A final category of loitering plus statutes are laws that proscribe loitering that causes a justifiable and reasonable alarm for the safety of persons or property. ${ }^{182}$ These statutes generally include a hist of circumstances that inay be considered, a requirement that the arresting officer give the accused an opportunity to explain his or her presence prior to arrest, and a requirement that it appear at trial that the explanation given was not true or would not have dispelled the alarm. ${ }^{183}$ Listed circumstances nay include "that the person takes flight upon appearance of a law enforcement officer, refuses to identify himself, or manifestly endeavors to conceal himself or any

180. See, e.g., $V J W, 680 \mathrm{P} .2 \mathrm{~d}$ at 1070-71 (upholding a Seattle ordinance proscribing loitering if the person "remains in a public place and intentionally solicits, induces, entices, or procures another to commit prostitution"); Jones, 475 P.2d at 792 (upholding an ordinance proscribing loitcring "in a manner and under circumstances manifesting a purpose of inducing, enticing, solieiting or procuring another to commit an act of prostitution" as construed to require specific intent as well as an overt act); Wilson, 291 N.W.2d at 458 (upholding ordinance proscribing loitering in a manner and under circumstances manifesting a purpose to solicit an act of prostitution and explicitly requiring specific intent).

181. See Carson, 569 F. Supp. at 975,980 (holding unconstitutionally overbroad an ordinance proscribing loitering "in a manner and under circumstances manifesting a purpose of indueing, entieing, soliciting, or procuring another to commit an act of prostitution," where ordinance is not construcd to require specific intent); Brown, 584 P.2d at 36-38 (holding unconstitutionally vague an ordinance proscribing loitering in a manner and under circumstances manifesting a purpose of inducing, enticing, soliciting, or procuring another to commit an act of prostitution," where no specific intent is required); Wyche, 619 So. $2 \mathrm{~d}$ at $233 \mathrm{n} .2,234-36$ (holding unconstitutionally vague and overbroad an ordinance proscribing loitering "in a manner and under circumstances manifesting a purpose of inducing, enticing, soliciting, or procuring another to commit an act of prostitution," where no specific intent is required); Profit, 517 P.2d at 251 (holding unconstitutionally overbroad an ordinanee proscribing loitering "in a manner and under circumstances manifesting a purpose of inducing, enticing, soliciting or procuring another to commit an act of prostitution," where no specific intent is required).

182. See, e.g., Watts v. State, 463 So. 2d 205, 205 n.1, 207 (Fla. 1985) (upholding an ordinance forbidding loitering or prowling "in a place, at a time or in a manner not usual for law-abiding individuals, under circumstances that warrant a justifiable and reasonable alarm or immediate concern for the safety of persons or property," despite United States Supreme Court's decision in Kolender v. Lawson, 461 U.S. 352 (1983), discussed infra text accompanying notes 191-95); Bell v. State, 313 S.E.2d $678,679,682$ (Ga. 1984) (upholding a statute proscribing loitering or prowling "in a place at a time or in a manner not usual for law-abiding individuals under circumstances that warrant a justifiable and reasonable alarm or immediate concern for the safety of persons or property'); City of Milwaukce v. Nelson, 439 N.W.2d 562, $563 \mathrm{n} .1,569$ (Wis. 1989) (upholding a statute probibiting loitering or prowling "in a place, at a time, or in a manner not usual for law-abiding individuals under circumstances that warrant alarm for the safety of persons or property"), cert. denied, 493 U.S. 858 (1989). But see City of Portland v. White, 495 P.2d 778, 778, 780 (Or. Ct. App. 1972) (holding unconstitutionally vague a statute forbidding loitering or prowling "in a place, at a time, or in a manner not usual for law abiding persons under circumstances that warrant alarm for the safcty of persons or property"); City of Bellevue v. Miller, 536 P.2d 603, 605, 608 (Wash. 1975) (holding unconstitutionally vague a statute proscribing wandering or prowling "in a place, at a time, or in a manner, and under circumstances, which manifcst an unlawful purpose or which warrant alarm for the safety of persons or property").

183. See, e.g., State v. Ecker, 311 So. 2d 104, 106 (Fla.), cert. denied, 423 U.S. 1019 (1975). 
object."184 These ordinances have been applied, for example, to a person hiding in the bushes at a private dwelling who fled upon the arrival of a police officer, ${ }^{185}$ and to a inan looking into parked cars who walked away froin and later fled froin an approaching police officer. ${ }^{186}$

Courts have split on whether these ordinances are valid. ${ }^{187}$ In upholding such an ordinance, the Florida Supreine Court in State v. Ecker noted that, under Terry $v$. Ohio, ${ }^{188}$ police officers nnay stop and frisk suspects without probable cause if a breach of peace is imminent or the public safety is threatened. ${ }^{189}$ Thus, according to the Ecker court, requiring a person to furnish credible and reliable identification where a threat to public safety exists was not unconstitutional. ${ }^{190}$

After the United States Supreme Court found a statutory requirement of production of "credible and reliable" identification unconstitutionally vague in Kolender v. Lawson, ${ }^{191}$ the Florida Supreme Court agaim reviewed the same ordinance at issue in Ecker. ${ }^{192}$ In Watts v. State, the court stated that the Kolender decision does not affect the validity of the Florida ordinance because a failure to provide identification is not an element of the offense. ${ }^{193}$ This reasoning seems disingenuous, however, because in Ecker the court stated that justifiable and reasonable alarm "is presumed under the statute if, when a law officer appears, the defendant flees, conceals himself, or refuses to identify himself."194

Far more persuasive is the reasoning of courts that have invalidated ordinances proscribing loitering that causes a justifiable and reasonable alarm for the safety of persons or property. One court noted that this type of ordinance does not require probable cause to believe that a crime has been committed. Rather, these statutes require only "justifiable alarm," which is merely a belief that a suspect is about to commit an unspecified crime. ${ }^{195}$ Similarly, another court reinarked that "[s]uch a basis for arrest, predicated upon nothing more than an officer's suspicion ... contravenes the traditional reluctance in our jurisprudence to punish individuals for anticipated but as yet uncommitted, or suspected but unknown crimes."196

184. Id.

185. Id. at 110 .

186. Watts, 463 So. $2 \mathrm{~d}$ at 205.

187. See supra note 182.

188. 392 U.S. 1 (1968).

189. Ecker, 311 So. 2d at 109 (citing Terry, 392 U.S. at 21).

190. $\mathrm{Id}$.

191. 461 U.S. 352, 360-61 (1983).

192. See Watts v. State, 463 So. 2d 205 (Fla. 1985).

193. Id, at 207.

194. Ecker, 311 So. $2 \mathrm{~d}$ at 106.

195. See City of Portland v. White, 495 P.2d 778, 780 \& n.l (Or. Ct. App. 1972) (invalidating statute as unconstitutionally void for vagueness).

196. City of Bellevue v. Miller, 536 P.2d 603, 607 (Wash. 1975) (invalidating statute as unconstitutionally vague). The court added that an "[a]rrest must be grounded upon a more substantial basis than police hunch." Id. 
In her dissent in City of Milwaukee v. Nelson, ${ }^{197}$ Wisconsin Supreine Court Justice Abrahamson noted that the ordinance at issue did not require any specific intent to commit a crime. ${ }^{198}$ Abrahamson added that the requirement that it appear to the trial court as well as to the arresting officer that any explanation given was not true or would not have dispelled the alarm "in no sense obviates the constitutional requirement that laws imclude minimal guidelines to govern law enforcement officials." 199 As the United States Supreme Court noted in Kolender, " '[i]t would certainly be dangerous if the legislature could set a net large enough to catch all possible offenders, and leave to the courts to step imside and say who could be rightfully detained, and who should be set at large." "200 Thus, because this ordinance, and others like it, criminalize conduct without requiring probable cause or specific criminal intent, they reach a substantial ainount of constitutionally protected conduct and are unlikely to survive future vagueness and overbreadth challenges. ${ }^{201}$

\section{Other Factors Affecting Vagueness and Overbreadth Analysis}

Several other factors tend to play a role in vagueness and overbreadth decisions. First, federal courts are much inore hikely to strike down a state or local statute than a federal statute. ${ }^{202}$ This discrepancy stems from the federal courts' ability to place a limiting construction on a federal statute, instead of relying on a state court's construction of state or local laws. ${ }^{203}$ Second, courts tend to strike down criminal laws more often than civil laws. ${ }^{204}$ This practice is consistent with the goal of providing breathing space for First Amendinent freedoms, simce the more severe the penalty, the more likely it is that persons will be deterred from exercising their First Amendınent rights. ${ }^{205}$ Finally, courts are more likely to invalidate statutes whose enforceinent authority is diffused rather than centralized, since such statutes are less likely to be enforced in a consistent and predictable manner and are, therefore, less amenable to judicial review. ${ }^{206}$

197. 439 N.W.2d 562 (Wis. 1989).

198. Id. at 577 (Abrahamson, J., dissenting).

199. Id.

200. 461 U.S. 352,358 n.7 (quoting United States v. Reese, 92 U.S. 214, 221 (1876)).

201. In fact, the Florida Supreme Court, after upholding the constitutionality of the ordinance in Ecker, affirmed the conviction of only one of the four defendants in the case. See Ecker, 311 So. $2 d$ at 110-11.

202. See Gartenstein \& Warganz, supra note 82 , at $510-12$.

203. Id.; Amsterdam, supra note 17, at 86-87.

204. Gartenstein \& Warganz, supra note 82, at 508-10; Amsterdam, supra note 17, at 69 n.16.

205. See Amsterdam, supra note 17 , at 94.

206. See Jeffries, supra note 17 , at 216 . 
IV

\section{The Constitutionality of the Chicago Ordinance}

The Chicago Ordinance will not likely survive vagueness and overbreadth challenges. A violation of the Ordinance requires four separate elements: (1) loitering, (2) by two or more persons, (3) one of whom is a criminal street gang member, (4) followed by a failure to promptly obey a police order to disperse and remove themselves. ${ }^{207}$ As such, the Ordinance requires more than mere loitering. However, the additional elements do not narrowly restrict the statute's reach to loitering whicl is either part of a criminal attempt or part of conduct that significantly infringes on the riglits of others. Accordingly, the Ordinance will fail constitutional challenges for vagueness and overbreadth. ${ }^{208}$

\section{A. The Notice that the Ordinance Provides Will Not Save it from Invalidation}

Under the Ordinance, liability only attaches if a suspect fails to disperse after being asked by a police officer to do so. One wlio lias been asked to disperse and refuses cannot claim a lack of notice. However, given the lack of actual notice required under our legal system, the fair warning rationale is unpersuasive. ${ }^{209}$ Accordingly, the actual notice that a loitering statute provides will liave little impact on its constitutionality. ${ }^{210}$ As a result, the explicit notice provided by the police order to disperse will not save the Ordmance from invalidation.

\section{B. The Ordinance Sweeps Within its Coverage a Significant Amount of Activity that is Generally Innocent and Constitutionally Protected}

The United States Supreme Court lias indicated that loitering is substantively innocent and an individual freedom worthy of protection. ${ }^{211}$ Accordingly, a statute must proscribe more than mere loitering to survive constitutional attack. While the Ordinance requires additional elements beyond loitering, these elements fail to restrict the Ordinance to properly proscribed behavior.

\section{Remaining in One Place With No Apparent Purpose}

The Ordinance's definition of loitering as "to remain in any one place with no apparent purpose"212 does not adequately restrict the Ordinance's scope. Specifically, this language appears indistinguishable from the lan-

207. See ChICAgo, ILL., MuN. CODE § 8-4-015 (1993), supra note 2; supra text accompanying notes 63-66.

208. See supra text accompanying notes $163-68$.

209. See supra text accompanying notes 72-75.

210. See supra notes $105-14$ and accompanying text.

211. See supra notes $122-25$ and accompanying text.

212. See Chicago, IlL., Mun. Code § 8-4-015(c)(1) (1993), supra note 2. 
guage of the Papachristou ordinance which proscribed wandering or strolling "without any lawful purpose or object."213 For example, a New York court, relying in part on Papachristou, invalidated a statute proscribing loitering "without apparent reason."214 In essence, remaining in one place with no apparent purpose is merely a definition of loitering as it is coininonly understood, and thus fails to distinguish the Ordinance from a general loitering law.

\section{Refusal to Obey a Police Order to Disperse}

The Ordinance's requirement of a refusal to obey a police order to disperse will not save it from invalidation. In Shuttlesworth $v$. City of Birmingham, the United States Supreme Court held that "the inere refusal to move on after a police officer's requesting that a person standing or loitering should do so is not enough to support the offense." "215 Thus, the Ordinance's dispersement request requirement does not convert substantively innocent activity into activity that can be properly proscribed.

\section{Loitering by Two or More Persons}

Likewise, the Ordinance's requirement of loitering by two or more persons fails to restrict adequately the Ordinance's scope. In fact, this requireinent increases the likelihood that people will be punished for, or deterred from, exercising their First Amendment rights of free association and asseinbly. In light of the vagueness and overbreadth doctrines' coinmon goal of preventing such a chilling effect on First Amendment freedoms, the requirement of two or niore persons will likely only heighten judicial scrutiny.

\section{At Least One "Criminal Street Gang Member"}

The City both sought to prevent crime and inaintain the Ordinance's constitutionality by liniting the Ordinance's application to situations where at least one loiterer is a "criminal street gang meinber."216 However, past

213. Papachristou v. City of Jacksonville, 405 U.S. 156, 156 n.1 (1972).

214. People v. Bambino, 329 N.Y.S.2d 922, 927-29 (N.Y. County Ct. 1972).

215. 382 U.S. 87, 90-91 (1965) (quoting Middlebrooks v. City of Birmingham, 170 So. 2d 424, 426 (Ala. Ct. App.), cert. denied, 170 So. 2d 427 (Ala. 1964)).

216. See ChICAGo, IlL., MuN. CODE § 8-4-015(a); the ordinance is set forth in full supra note 2. The Ordinance uses language similar to that found in the Racketeer lnfluenced and Corrupt Organizations Act (RICO). The Ordinance defines "criminal street gang" as "any ongoing organization, association in fact or group of three or more persons, whether formal or informal, having as one of its substantial activities the commission of [certain enumerated criminal acts], and whose members individually or collectively engage in or have engaged in a pattem of criminal gang activity." Id. at (c)(2). A "pattem of criminal gang activity" means "two or more acts of criminal gang activity of which at least two such acts were committed within five years of each other and at least one such act occurred after the effective date of this Section." Id. at (c)(4).

Similarly, section 1962 of RICO makes it a crime to use money or invest in, acquire or maintain control in, or conduct or participate in an "enterprise" through a "pattern" of raeketcering activity. 18 U.S.C. $§ 1962(a)-(c)(1988)$. An "enterprise" is broadly defined to include "any individual, partnership, 
vagueness and overbreadth challenges indicate that "status" requireinents ${ }^{217}$ will not adequately narrow an otherwise overbroad statute. ${ }^{218}$

For example, in Aptheker $v$. Secretary of State, ${ }^{219}$ the United States Supreme Court reviewed a section of the Subversive Activities Control Act of 1950, which inade it a felony for a registered meinber of a communist orgamization to apply for, use, or attempt to use a passport. ${ }^{220}$ After noting a congressional intent to protect national security, ${ }^{221}$ the Court described how the section's requirement of membership in a communist orgamization failed to narrowly restrict its scope to activity that threatens national security. In so holding, the Court asserted that even if some ineinbers of communist organizations engaged in illegal activity, it does not follow that all members did so. ${ }^{222}$ Moreover, because the section applied to all travel,

corporation, association, or other legal entity, and any union or group of individuals associated in fact although not a legal entity." 18 U.S.C. $\$ 1961$ (4) (1988). A "pattern of racketeering activity" is defined as committing at least two acts of racketeering, with at least one act occurring after the effective date of the statute, and the subsequent act occurring within ten years of the first act. 18 U.S.C. $\S 1961(5)$ (1988).

Despite their similar language, the RICO statute and the Chicago Ordinance have different purposes. The Chicago Ordinance was apparently not enacted with the intent of dismantling street gangs by identifying them and criminalizing operating or participating in a street gang. Rather, the Ordinance was aimed at preserving the city streets and other public areas so that citizens could use these places without fear of crime or violence. See Chicago, Ill., Mun. Code § 8-4-015 (1993) (Preamble). In contrast, Congress enacted RICO to dismantle criminal organizations by providing severe penalties for operating and participating in criminal organizations, and by preventing such organizations from using their profits to infiltrate legitimate businesses. See Lesley S. Bonney, Comment, The Prosecution of Sophisticated Urban Street Gangs: A Proper Application of RICO, 42 CATH. U. L. REv. 579, 587-91 (1993). Thus, it is possible that RICO, or a local ordinance similar to RICO, could be used to dismantle gangs altogether. See generally id. (arguing that using the RICO statute to prosecute sophisticated urban street gangs is not only proper, but necessary in order to eliminate today's brand of organizad crime). But see Alexander A. Molina, California's Anti-Gang Street Terrorism Enforcement and Prevention Act: One Step Forward, Two Steps Back?, 22 Sw. U. L. REv. 457 (1993) (arguing that California's Anti-Gang Street Terrorism Enforcement and Prevention Act, modeled after RICO and making it unlawful for an individual to join a gang or assist in its unlawful activities, is unconstitutional).

217. Most loitering statutes do not explicitly contain a status element. However, ordinances that prohibit loitering that manifests a purpose to engage in either drug-related activity or prostitution often list a person's status as a known drug-user or prostitute, respectively, as circumstances manifesting such purposes. See text accompanying notes 173-82. As discussed earlier, where such an ordinance is not interpreted as requiring a specific intent to engage in a crime, it is usually struck down. Id.

218. Note that the issue of whether a status requirement can adequately narrow the scope of an otlierwise overly vague or overbroad statute is distinct from the issue of whether the Eighth Amendment prevents a state from punishing mere status without proof of some forbidden act. See LAFAVE AND ScorT, supra note $165, \S 2.14(\mathrm{f})$, at 182-84. In Robinson v. California, 370 U.S. 660,667 (1962), the United States Supreme Court held that a statute making it a crime for a person to be addicted to narcotics was unconstitutional because it imposed crnel and unusual punishment in violation of the Eighth Amendment. However, the Court based its decision both on the fact that the statute did not require proof of any irregular behavior and that the status being punished was an illness that could be contracted innocently or involuntarily. Id. Thus, the Court left open the question of whether the Eighth Amendment prohibits a state from punishing a person based on a status that is voluntarily or culpably attained.

219. 378 U.S. 500 (1964).

220. Id. at 501-02.

221. Id. at 509.

222. Id. at 510-11 (quoting Schware v. Board of Bar Examiners, 353 U.S. 232, 246 (1957)). 
regardless of its purpose, a member of a communist organization could not apply for a passport "to visit a sick relative, to receive medical treatment, or for any other wholly innocent purpose."223 In striking down the section as unconstitutional, the Court stated that it "sweeps too widely and too indiscriminately across the liberties guaranteed in the Fifth Amendment."224

Similarly, in Johnson v. Carson, ${ }^{225}$ a federal district court invalidated an ordinance that prohibited loitering in a inanner manifesting the purpose of prostitution where the purpose element is satisfied by showing that the person loitering is a "known prostitute."226 Noting that the ordinance applied to such constitutionally protected conduct as window shopping, waiting for a bus, or spending time idly, the court concluded that the ordinance impermissibly "chilled" the free exercise of known prostitutes' First Amendment rights. ${ }^{227}$

In Brown v. Municipality of Anchorage, ${ }^{228}$ the Alaska Supreme Court found a nearly identical ordinance unconstitutionally vague. ${ }^{229}$ In contrast to Carson, the court in Brown einphasized the ordinance's potential for arbitrary enforcement. 230 In fact, under the ordinance, "a previously convicted prostitute or panderer could stand on a public street corner or walk slowly down a public sidewalk only at the whim of any police officer."231

Like the status requirenents in these invalidated ordinances, the Chicago Ordmance's requirement that at least one loiterer be a criminal street gang meinber fails to narrowly restrict the scope of the Ordinance to activities that significantly infringe on the rights or interests of others. Specifically, the Ordimance does not adequately distinguish between activity that justifiably prevents citizens from using public streets and places, and activity that is generally innocent and constitutionally protected.

Following the Supreme Court's approach in Aptheker, applications of the Ordinance to mere loitering and to other activities that are generally innocent and constitutionally protected can be easily imagined. When a group of gang members gather on a sidewalk, they are likely to intiinidate, and know that they are intimidating, others froin passing through that area. Such activity significantly infringes on other citizens' legitimate use of public areas and falls squarely within the Ordinance's coverage. ${ }^{232}$ But by its terins, the Ordinance also clearly forbids two or more persons, one of whom is a gang member, froin sitting on a park bench, window shopping, or just

223. Id. at 511 .

224. Id. at 514 .

225. 569 F. Supp. 974 (M.D. Fla. 1983).

226. Id. at 978,980 .

227. Id. at 978-79.

228. 584 P.2d 35 (Alaska 1978).

229. Id. at 38 .

230. Id.

231. Id. at 37.

232. ChICAGO, ILL., MUN. CODE $\$ 8-4-015$ (a); the entire ordinance is set forth supra note 2. 
chatting. In fact, the Ordinance would proscribe those activities even if the gang member were doing any of them with his parents. The Ordinance would also punish one or more members of a community outreach group standing on a corner and imploring a gang member to leave the gang. In the above scenarios, it is unlikely that the public would be intimidated from using the streets and other public areas. The Ordinance, however, fails to distinguish between intimidating and non-intimidating behavior. Thus, even considering the gang member requirement, the Ordinance reaches a significant amount of generally innocent and constitutionally protected activity.

As a result, the Ordinance, like the ordinances in Carson and Brown, ${ }^{233}$ creates a chilling effect and a risk of arbitrary and discriminatory enforcement. First, gang members and persons who live in areas where gangs are prevalent will be deterred from loitering and potentially deterred from exercising their First Amendinent rights of free speech, free association, and free assembly. Second, the Ordinance creates the risk of arbitrary enforcement because it applies equally to activity that is intimidating and to activity that is innocent and non-threatening. Like the ordinance at issue in Brown, a street gang meinber and anyone with him can "stand on a public street corner or walk slowly down a public sidewalk only at the whim of any police officer."234 The Ordinance's requirement that at least one loiterer be a gang member does not reduce the risk of discriminatory enforcement. $^{235}$ Indeed, the focus on gang members makes discriminatory enforcement more likely. For example, a law enforcement officer might arrest gang members loitering on a sidewalk, but look the other way when ordinary high school students engage in the very same conduct. By its very terins, the statute forces officers to focus not on the imtimidating behavior itself but on the status of the particular loiterer.

\section{$\mathrm{V}$}

\section{Drafting a Constitutional Solution}

The City of Chicago has an undeniably legitimate interest in protecting its streets and other public areas so that the public may use such places without fear. Local governments are free to criminalize activity that significantly infringes on the interests and rights of their citizens, including activity that obstructs or hinders the use of city streets and sidewalks. ${ }^{236}$ Moreover, street gangs represent a threat to the free use of city streets and

233. See supra text accompanying notes 225-32.

234. Brown v. Municipality of Anchorage, 584 P.2d 35, 37 (Alaska 1978).

235. Even without such a requirement, courts would suspect that the police would aim their enforcement toward gang members, given society's general disdain for street gangs, the fact that no realistic attempt could be made to indiscriminately stop all loitering by two or more persons, and in light of the long history of abuse associated with general loitering laws. See supra text accompanying notes 132-38.

236. Coates v. City of Cincinnati, 402 U.S. 611,614 (1971). 
public places by creating "turf," where they establish control over public areas by loitering there and intimidating others from using those areas. ${ }^{237}$ However, in order to survive constitutional attack, an ordinance must do more than merely distinguish gang members based solely on their status as such. Rather, the ordinance must adequately distinguish between activity that actually prevents citizens from using public streets and places, and activity that is generally innocent or constitutionally protected.

First, any requirement of two or more persons should be eliminated. While a group, as opposed to an individual, is more likely to reasonably intimidate citizens from passing along a sidewalk or other public area, a requirement of two or more persons is not needed. If obstructive conduct is proscribed, it will cover such conduct by any number of persons. Moreover, a requirement of two or more persons increases the likelihood that persons will be pumshed for, or deterred from, exercismg their First Amendment right of association. Thus, such a requirement only serves to heighten judicial scrutiny.

Second, the requirement that one of the loiterers be a criminal street gang member should also be elimmated. Like the status requirements in other loitering ordinances, the gang member requirement does not adequately narrow the scope of an otherwise overbroad ordinance. ${ }^{238}$ Specifcally, the gang member requirement forces officers to focus not on intimidating behavior itself, but on the status of the particular loiterer. As a result, the requirement does little to distinguish between intimidating and nonintimidating loitering, thereby allowing the Ordinance to rcach a signifcant amount of innocent activity such as sitting on a park bench, window shopping, or just chatting. ${ }^{239}$ Furthermore, requiring that one loiterer be a gang member may constitute a criminalization of status in violation of the Eighth Amendment. ${ }^{240}$

Most importantly, a constitutional ordinance must, unlike the current Ordinance, distinguish between activity that reasonably deters citizens from using public streets and places, and activity that is generally innocent or constitutionally protected. Specifically, an ordinance could provide:

It shall be unlawful, after having been warned by a law enforcement officer, for any person to loiter on any public street or sidewalk, or any other public area, so as to intimidate others from using any public street or sidewalk, or other public area.

This ordinance adequately distinguishes between activity that actually deters citizens from using public places, and activity that is generally innocent or constitutionally protected activity. First, the language is not overbroad. As previously discussed, assembling "in a manner annoying to

237. See supra text accompanying notes 20-24.

238. See supra text accompanying notes 216-36.

239. See supra text accompanying notes 231-36.

240. See supra note 218. 
persons passing by,"241 or loitering so as to only "tend to" hinder or impede ${ }^{242}$ does not significantly interfere with the rights of others to use public streets and places. But the proposed ordinance above does not reach such activity because the ordinance's scope is limited to loitering that is intimidating.

Nor is the tern "intimidate" so vague as to encompass a significant amount of activity that is generally innocent or constitutionally protected. For example, no reasonable person would be intimidated by a person sitting on a park bench, window shopping, or just chatting, or a gang nember doing any of the foregoing with his or her parents or inembers of a commumity outreach group. ${ }^{243}$ of course, a reasonable person may be intimidated when several gang members engage in these activities as a group. But such activity, in addition to being objectively intimidating, is not intended to be innocent. In these cases, gang nembers know or should know that they are intinidating others from using public places. As a result, prosecutors should be able to show that the gang nnembers intentionally or knowingly intimidated others.

However, this proposed ordinance or any other law directed at intimidation by street gangs presents several practical problems in enforceinent. First, as Susan Burrell has noted, there is no agreed-upon definition of gangs or method of determining gang membership. ${ }^{244}$ Social scientists report that the most common activities of gangs are "the same as those of many adolescent friendship groups-partying, hanging around and getting high." "245 Furthermore, many experts emphasize the unorganized and unplanned nature of gang activity. ${ }^{246}$ Because it is difficult to separate legitimate activities from illegal activities, law enforcement officials have

241. Coates v. City of Cincinnati, 402 U.S. 611, 611 (1971); see supra text accompanying notes 159-68.

242. Ciccarelli v. City of Key West, 321 So. $2 d$ 472, 474 (Fla. Dist. Ct. App. 1975) (invalidating ordinance on grounds of overbreadth); see supra text accompanying notes 169-72.

243. As an alternative to the ordinance proposed above, the City Council could enact an ordinance modeled after existing loitering plus statutes that proscribe loitering which obstructs or hinders free passage. Thus, an ordinance could provide:

It shall be unlawful after having been warned by a law enforcement officer for any person to loiter on any public street or sidewalk, or any other public area, so as to hinder or obstruct the frce passage of pedestrians or vehicles thereon.

Since similar statutes have generally survived challenges based on vagueness and overbreadth, precedent exists to support the constitutionality of a similar ordinance. See supra note 168 . However, in order for such an ordinance to be effective, "hinder or obstruct" would have to be defined or interpreted to include loitering that intimidates, as well as physically blocks, others from using public areas.

244. See Susan L. Burrell, Gang Evidence: Issues for Criminal Defense, 30 Santa Clara L. Rev. 739,748 (1990).

245. Id. at 748-49 (quoting John Moore, et al., Residence and Territoriality in Chicago Gangs, 31 Soc. Probs. 182, 186 (1983)).

246. Id. at 749. 
only recently attempted to define what constitutes a "gang" or "gang membership."247

Second, Burrell has observed that, even if a definition of "gang" is agreed upon, the concept of "membership" remaims elusive. ${ }^{248}$ Criminal street gangs do not simply "issue membership cards or hold weekly meetings" like many organizations. ${ }^{249}$ Rather, the loose structure of street gangs makes the identification of their members very difficult. ${ }^{250}$ In addition, the outward symbols of gang identity, notably clothing styles and signals, are often adopted by those not in gangs. For example, persons may wear baseball caps and baggy clothing simply as a matter of fashion. ${ }^{251}$ Moreover, law enforcement may imistake the above characteristics for the presence of a "new gang," when instead the persons involved are either only aspiring members, or only associate with gang members and know gang signs as a matter of survival in their neighborhoods. ${ }^{252}$ Finally, even if an actual gang member is identified, membership may convey little about that person's level of involvement or activity in the gang. ${ }^{253}$

Third, any law directed at intimidation by street gangs assumes that indicia of gang membership can be used to prove intimidation. Specifically, the presence of possible street gang members often intimidates others because of the association of street gangs with violence, drug-dealing, and vandalism. ${ }^{254}$ As a result, indicia of gang membership would almost always need to be admitted as evidence in order to prove that someone loitered so as to imtimidate others from using a public sidewalk or other public area. Such indicia typically take the form of baseball caps and baggy clothing. ${ }^{255}$

This use of visible indicia of gang membership to establish a criminal violation creates several problems. First, such use may violate defendants' First Amendment rights to freedom of speech and expression. Conduct that is nonverbal in nature but nonetheless has a communicative impact is sometimes given First Amendment protection. ${ }^{256}$ Choosing one's clothing may

247. Id.

248. Id. at 750 .

249. Id.

250. Id.

251. See Gordon Dillow, Police Bag the Baggy Pants Crowd in an Effort to Rid Mall of Gangs,

L.A. TIMES, December 31, 1993, at B3.

252. Jeffrey J. Mayer, Commentary, Individual Moral Responsibility and the Criminalization of Youth Gangs, 28 WAKE Forest L. REv. 943, 961-63 (1993).

253. See Burrell, supra note 244 , at 750 .

254. The Chicago City Council found this to be true in the Preamble to the Ordinance. See Chicago, Ill., Mun. Code § 8-4-015 (1993) (Preamble).

255. See Dillow, supra note 251.

256. See Paul D. Murphy, Note, Restricting Gang Clothing in Public Schools: Does a Dress Code Violate a Student's Right of Free Expression?, 64 S. CAL. L. REv. 1321, 1321-22 (1991); see generally N. Denise Burke, Commentary, Restricting Gang Clothing in the Public Schools, 80 Educ. L. REP. 513 (1993) (discussing whether public schools can restrict gang clothing without violating the constitutional rights of students); James A. Maloney, Comment, Constitutional Problems Surrounding the 
be just this type of nonverbal communication. ${ }^{257}$ Second, indicia of gang meinbership may be inadmissible as evidence at trial due to its highly prejudicial effect. ${ }^{258}$ Finally, there is the practical problem of confusing current fashion trends with actual gang clothing, as well as the difficulty of keeping up with the frequent changes in gang styles. ${ }^{259}$

\section{CONCLUSION}

The vagueness and overbreadth doctrines have effectively put an end to many past uses of loitering laws. No longer can local governments use mere loitering laws to arrest and convict suspicious persons as a ineans of crime prevention. In return, the individual citizen is less susceptible to arbitrary and discriminatory demals of their constitutionally guaranteed freedoins of speech and association.

Today's loitering laws must be precisely and narrowly drawn to apply to conduct that is culpable, or that significantly interferes with the rights or interest of others. Because state and local legislatures have always had the power to reach such conduct through other criminal laws, the use of loitering laws as a distinct ineans for achieving government ends is obsolete. Rather than constituting a separate criminal offense, loitering's role in today's criminal law is limited to serving as a descriptive element in other offenses such as obstruction of passage, intimidation, attempted prostitution, and illegal drug activity.

Nevertheless, the City of Chicago, like other cities across the United States, has both a legitimate interest in, and the power to prevent, the intimidation of its residents that often results from gang loitering. In doing so, however, the City must exercise its powers fairly and with care in order to avoid needlessly depriving its citizens, including gang nembers, of their freedoms.

Implementation of "Anti-Gang" Regulations in the Public Schools, 75 MARQ. L. Rev. 179 (1991) (discussing the constitutionality of several "anti-gang" regulations in public schools including dress codes).

257. Murphy, supra note 256, at 1322.

258. See Burrell, supra note 244, at 764.

259. See Murphy, supra note 256, at 1357. 
